\title{
Effects of irrigation water regime, soil clay content and their combination on growth, yield, and water use efficiency of rice grown in South China
}

\author{
Yousef Alhaj Hamoud ${ }^{1,2}$, Xiangping Guo ${ }^{1 *}$, Zhenchang Wang ${ }^{1}$, Sheng Chen ${ }^{1}$, Ghulam Rasool ${ }^{1}$ \\ (1. Key Laboratory of High-Effective Irrigation and Drainage and Agricultural Water and Soil Environment in Southern China \\ Ministry of Education, Hohai University, Nanjing 210098, Jiangsu, China; \\ 2. Department of Soil and Land Reclamation, Aleppo University, Aleppo 1319, Syria)
}

\begin{abstract}
To investigate the effect of irrigation regime, soil clay content and their combination on growth, yield, and water productivity of rice, a shelter experiment was conduct using Randomized Complete Block Design (RCBD) with a factorial arrangement of treatments with four replications. Irrigation regime was the main treatment investigated, set in three levels as $\mathrm{R}_{(30 \mathrm{~mm}-100 \%)}\left(100 \%\right.$ of saturation and $30 \mathrm{~mm}$ flooded), $\mathrm{R}_{(30 \mathrm{~mm}-90 \%)}\left(90 \%\right.$ of saturation and $30 \mathrm{~mm}$ flooded) and $\mathrm{R}_{(30 \mathrm{~mm}-70 \%)}(70 \%$ saturation and $30 \mathrm{~mm}$ flooded), respectively. The sub-treatment was soil type, set in three levels as $40 \%, 50 \%$ and $60 \%$ clay content, respectively. Results showed that irrigation regime and soil clay content had significant effects on growth, yield and water productivity of rice. However, their combination showed no significant impact on panicles number, root biomass, harvest index and irrigation water productivity. Higher soil clay content results in increase in growth, yield, and water productivity of rice. The total water consumption during $\mathrm{R}_{(30 \mathrm{~mm}-100 \%)}$ was higher than that during $\mathrm{R}_{(30 \mathrm{~mm}-90 \%)}$ and $\mathrm{R}_{(30 \mathrm{~mm}-70 \%)}$ because the latter two saturation levels led to the cracking of soil and decrease of total number of irrigations. Cracks were consistently getting more serious with the reduction in soil water content and the increase in soil clay content. Cracks in soil will preferentially become the major routes of water losses, thus water percolation during $\mathrm{R}_{(30 \mathrm{~mm}-70 \%)}$ was higher than that during $\mathrm{R}_{(30 \mathrm{~mm}-90 \%)}$ and $\mathrm{R}_{(30 \mathrm{~mm}-100 \%)}$ after each irrigation event. The total water use under $\mathrm{R}_{(30 \mathrm{~mm}-70 \%)}$ exceeded the water consumption under $\mathrm{R}_{(30 \mathrm{~mm}-90 \%)}$ due to the great amount of soil cracking as well as the excessive volume of standing water depth. Considering water consumption and grain yield, the following conclusion can be reached: (i) The reduction in water consumption was greater than the reduction in grain yield in the case of drying soil $10 \%$ below saturation before reflooding. (ii) The reduction in water consumption was less than the reduction in grain yield in the case of drying soil $30 \%$ below saturation before reflooding; (iii) The increase in water use was greater than the increase in grain yield in the case of maintaining soil moisture at $100 \%$ of saturation before reflooding. Therefore, the water use efficiency was recorded in the order of $\mathrm{R}_{(30 \mathrm{~mm}-90 \%)}>\mathrm{R}_{(30 \mathrm{~mm}-100 \%)}>\mathrm{R}_{(30 \mathrm{~mm}-70 \%) \text {. }}$
\end{abstract}

Keywords: irrigation regime, clay content, combination, growth, yield, water productivity, rice DOI: $10.25165 /$ j.ijabe.20181104.3895

Citation: Hamoud Y A, Guo X P, Wang Z C, Chen S, Rasool G. Effects of irrigation water regime, soil clay content and their combination on growth, yield, and water use efficiency of rice grown in South China. Int J Agric \& Biol Eng, 2018; 11(4): $144-155$

\section{Introduction}

Rice is cultivated in almost every region of China. It is the staple food for more than $65 \%$ of the Chinese people ${ }^{[1]}$ and feeds three billion people in the world ${ }^{[2]}$. The planting area for rice occupies about $23 \%$ of all cultivated land in China ${ }^{[3]}$. It is a water-loving crop and requires a large amount of freshwater under the flood-irrigated conditions. China owns less than $25 \%$ of the world average water resources per capita ${ }^{[4]}$, recognized for its shortage in water resources. Even facing the increasing competition for water from the agriculture and other sectors in

\section{Received date: 2017-10-06 Accepted date: 2018-03-16}

Biographies: Yousef Alhaj Hamoud, $\mathrm{PhD}$ candidate, research interests: agricultural soil, plant and water relations, Email: yousef-hamoud11@ hotmail.com; Zhenchang Wang, PhD, Associate Professor, research interests: deficit irrigation, Email: wangzhenchang@hhu.edu.cn; Sheng Chen, PhD, Post-doctor, research interests: agricultural water engineering, Email: 15950467154@163.com; Ghulam Rasool, PhD candidate, research interests: agricultural soil and water engineering, Email: gr_uaf@yahoo.com.

*Corresponding author: Xiangping Guo, $\mathrm{PhD}$, Professor, research interests: soil and water engineering. No. 1 Xikang Road, Nanjing 210098, Jiangsu, China. Tel: +86-13851560470, Fax: +86-25-83786511, Email: xpguo@hhu.edu.cn. addition to growing population, the rice cultivation alone uses approximately $50 \%$ of the Chinese freshwater resources ${ }^{[5]}$, in which $95 \%$ or more of the rice is cultivated in China under the flood-irrigated conditions ${ }^{[6]}$. For solving the water shortage and improving the water use efficiency, several innovative water-saving irrigation technologies have been adopted.

Alternate wetting and drying (AWD) irrigation ${ }^{[7,8]}$ has been widely implemented in many areas in China ${ }^{[9]}$. In this water-saving technology, alternative flooded and non-flooded conditions are practiced in the field ${ }^{[10,11]}$. After irrigation, the depth of standing water will gradually decrease. When the water level dropped below the surface of the soil, irrigation is applied to re-flood the field with $5 \mathrm{~cm}$ of ponded water. Although around $15 \%-30 \%$ of water inputs can be saved from AWD system compared with traditional continuously flood irrigation ${ }^{[12,9]}$, the efficiency varied greatly with soil type, and hydrological conditions, and AWD system often decreased the rice yield ${ }^{[7]}$. Soil texture affects the movement and availability of air and water in soil, influences root growth, water and nutrient uptake and overall plant growth. Usually, paddy soil contains more clay, which is the most important component of mineral soil due to its very high specific surface area and consequently its ability to hold nutrients 
and water. When the soil contains at least $35 \%$ of clay separate, it is designated as clay-textured soil where the characteristics of the clay separate are distinctly dominating. The formation of cracks in clay-textured soils is a natural phenomenon and physical manner with important agricultural repercussions. Soil desiccation is mainly governed by the properties that vary in space such as moisture content and clay content ${ }^{[13]}$. A great amount of clay in soil results in large specific surface are ${ }^{[14]}$, thus results great shrink-swell potential of the soil. Further studies displayed a positive and strong correlation between expansive soil potential and total clay content ${ }^{[15]}$. Since water is the main governing factor for shrinking and swelling of soils and development of fractures, irrigation regime is as important as soil clay content on this aspect. In flooded or saturated paddy field, soil swelling is widely recognized because the fine clay absorbs water. In AWD, the paddy soil is allowed to dry out to some certain degree before next round irrigation ${ }^{[8]}$, at that time the top layer of the soil cracks due to the removal of water from within and between clay microstructures. During the irrigation-dry out cycles, the increase in occurrence and extent of cracks results in significantly higher penetration rate ${ }^{[16]}$, permitted quicker and deeper seepage of water and nutrients into the subsoil ${ }^{[17]}$. Such leaching to down root zone makes water and nutrient inaccessible to shallow roots ${ }^{[18]}$, resulting in the increase in percolation rate as well as the reduction in water productivity ${ }^{[8]}$. Therefore; cracks influence root development and nutrient and water absorbance, further influences the process of plant growth and development in soils ${ }^{[19,20]}$. Also, desiccation cracks serve as secondary evaporation plates to increases the evaporation of water from cracked soils ${ }^{[21]}$, further decreased water use efficiency ${ }^{[22]}$.

In south China regions flooding irrigation is still practiced by Chinse farmers for rice cultivation, which is not advisable due to water shortage. AWD cycles are extensively recommended although such cycles have implications for other aspects of the rice production system including soil cracking. Therefore, the main objectives of the present study were to assess the effects of irrigation regime, soil clay content and their combination on growth and development of rice. Since most irrigated lowland paddy soils in south China regions can be classified into clay ${ }^{[23]}$, silt clay $^{[11]}$ and clay loam ${ }^{[9]}$, this study also aimed to determine the effects of irrigation method, soil texture with their interaction on water consumption as well as on grain yield, dry matter production, and water use efficiency of rice.

\section{Materials and methods}

\subsection{Experimental site, soil preparation, and trial pipe setting} up

The experiment was conducted from July to October 2016 at the Water Saving Park Agricultural Experimental Farm in Soil, and Water Engineering Department, Hohai University, Nanjing, China. The farm is situated at $31^{\circ} 95^{\prime} \mathrm{N}, 118^{\circ} 83^{\prime} \mathrm{E}$, in a suburb of Nanjing at a Yangtze River drainage basin area with an average elevation of $15 \mathrm{~m}$ above the sea level. This area is characterized by humid subtropical climate and is under the influence of the East Asia Monsoon, with average annual rainfall of $1062 \mathrm{~mm}$. The annual mean temperature is $15.5^{\circ} \mathrm{C}$ with a monthly mean ranging from $2.4-27.8^{\circ} \mathrm{C}$; the highest recorded temperature of the area is $43.0^{\circ} \mathrm{C}$ while the lowest is $-16.9^{\circ} \mathrm{C}$.

Soil sample of $700 \mathrm{~kg}$ was collected by using a shovel from the top layer of 0-20 cm. After well dried, ground and sieved $(5 \mathrm{~mm})$, $50 \mathrm{~kg}$ pure clay was collected from sub-amount of the original soil by sedimentation in water, and then dried and ground to fine powder. Various types of soil were manufactured by the adjustment of clay content in the mother soil, which was called $\mathrm{S}_{(40 \%)}$ since the clay content of mother soil was $40 \%$. Soil containing $50 \%$ clay was prepared by mixing $16 \mathrm{~kg}$ of pure clay isolated with $80 \mathrm{~kg}$ of the mother soil, and soil comprising $60 \%$ was obtained by blending $32 \mathrm{~kg}$ of pure clay with $64 \mathrm{~kg}$ of the mother soil.

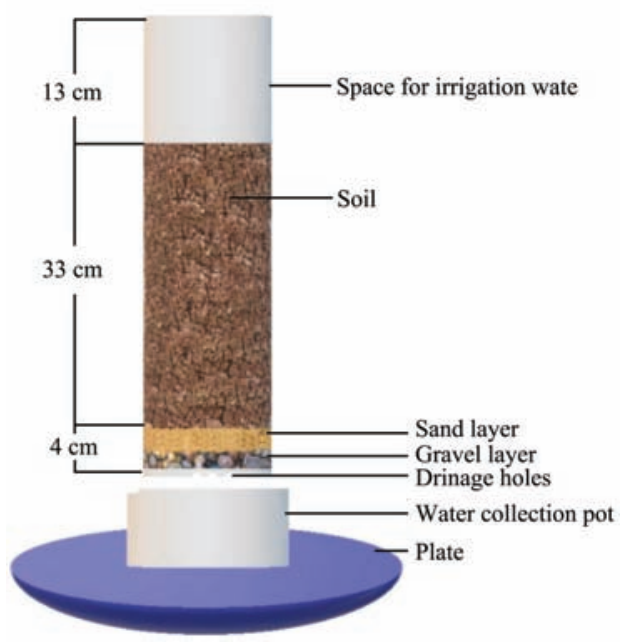

Figure 1 Experimental pipe setting up

Under temporary shelter covered with plastic film, 36 PVC pipes (L: $50 \mathrm{~cm}, \mathrm{r}: 16 \mathrm{~cm}$ ) with small holes at the base were installed as experimental group. Each pipe was filled by $8 \mathrm{~kg}$ dry soil leaving $13 \mathrm{~cm}$ spaces at the top of the tube, and $2 \mathrm{~cm}$ layer of gravel followed by $2 \mathrm{~cm}$ layer of sand was placed in the pipe's bottom as filter. The filter can enable the water infiltrated as it passes down through the soil, prevents the clay loss as well. A properly removable pot was installed in the pipe base to collect percolation water (Figure 1). The pipe itself weights $1.778 \mathrm{~kg}$, and the filter weights $1.222 \mathrm{~kg}$. Total weight of the pipe was $11 \mathrm{~kg}$. three more tubes filled with $8 \mathrm{~kg}$ of each types of soil were installed as control group (not planted), and water was supplied until the soils were aggregated and taken their structures. Control pipes were used to measure soil bulk density.

\subsection{Soil analysis}

Soil texture was determined by using Bouyoucos hydrometer (TM-85, China $)^{[24]}$. Soil bulk density was determined by measuring the mass of oven-dry soil in a sleeve of known volume (diameter $5 \mathrm{~cm}$ and height $5 \mathrm{~cm}$ ). The water content of the soil in this sleeve was calculated by measuring the weight difference before and after drying at $105^{\circ} \mathrm{C}^{[25]}$. Soil saturation was calculated based on the bulk density of $2.65 \mathrm{~g} / \mathrm{cm}^{3}$ as particulate density for mineral soil. Soil $\mathrm{pH}$ was measured by mixing soil and water in 1:5 ratio and measured the $\mathrm{pH}$ value of extract liquid using calibrated $\mathrm{pH}$ meter ${ }^{[26]}$. Electrical Conductivity (EC) of soil extract filtered was measured by EC meter ${ }^{[27]}$. Soil organic content was measured according to the oxidation method ${ }^{[28]}$. $2 \mathrm{~g}$ of soil sample was digested within a mixture of Selenium sulfate and Salicylic acid using a hotplate. Digestion was conducted at $100^{\circ} \mathrm{C}$ for $30 \mathrm{~min}$ then increased to $380^{\circ} \mathrm{C}$ for $3 \mathrm{~h}^{[29]}$. Total nitrogen in respective digest was measured using spectrophotometer (UV1901, China) ${ }^{[30]}$. Soil available nitrogen was measured using spectrophotometric method ${ }^{[31,32]}$. Soil available phosphorus was measured according to spectrophotometric method ${ }^{[33]}$. Soil available potassium was determined using flame photometer (Bromide, China) ${ }^{[29]}$. The soil physical and chemical properties are shown in Table 1. 
Table 1 Soil physical and chemical properties

\begin{tabular}{lccc}
\hline \multicolumn{1}{c}{ Propriety } & Soil $_{(40 \%)}$ & Soil $_{(50 \%)}$ & Soil $_{(60 \%)}$ \\
\hline Soil texture class & Clay & Clay & Clay \\
Sand $\%$ & 20.81 & 11.37 & 3.53 \\
Silt $\%$ & 38.94 & 39.10 & 36.50 \\
Clay $\%$ & 40.25 & 49.53 & 59.97 \\
Bulk density $/ \mathrm{g} \cdot \mathrm{cm}^{-3}$ & 1.29 & 1.21 & 1.12 \\
Saturation $/ \%$ & 51.32 & 54.33 & 57.73 \\
pH value & 6.25 & 6.88 & 6.94 \\
Electrical Conductivity ds $\cdot \mathrm{cm}^{-1}$ & 0.379 & 0.332 & 0.311 \\
Total Nitrogen $/ \mathrm{g} \cdot \mathrm{kg}{ }^{-1}$ & 1.09 & 0.76 & 0.68 \\
Mineral Nitrogen $/ \mathrm{mg} \cdot \mathrm{kg}^{-1}$ & 34.80 & 21.60 & 17.30 \\
Available Phosphorus $/ \mathrm{mg}^{-1} \mathrm{~kg}^{-1}$ & 16.20 & 12.90 & 10.40 \\
Available Potassium $/ \mathrm{mg} \cdot \mathrm{kg}^{-1}$ & 88.67 & 71.25 & 56.43 \\
Total Organic Carbone $/ \%$ & 1.86 & 1.22 & 1.05 \\
\hline
\end{tabular}

Note: Values are means of three replications for each measured propriety.

\subsection{Experimental design and irrigation regimes}

The experiment was arranged in Randomized Complete Block
Design composed of two factors that were irrigation regime and soil clay content, with four replications. The main treatment was irrigation regime-irrigation with $30 \mathrm{~mm}$ (upper limit) as the soil water content reached $100 \%$ of saturation (lower limit) $\mathrm{R}_{(30 \mathrm{~mm}-100 \%)}$; irrigation with $30 \mathrm{~mm}$ (upper limit) as the soil water content reaches $90 \%$ of saturation $\mathrm{R}_{(30 \mathrm{~mm}-90 \%)}$; irrigation with $30 \mathrm{~mm}$ (upper limit) as the soil water content reaches $70 \%$ of saturation (lower limit) $\mathrm{R}_{(30 \mathrm{~mm}-70 \%)}$. The sub-treatment was soil type, with a clay content of $40 \%, 50 \%$ and $60 \%$, which were marked as $\mathrm{S}_{(40 \%)}$, $\mathrm{S}_{(50 \%)}$ and $\mathrm{S}_{(60 \%)}$ respectively. The main treatments and sub-treatments that were used in this study are shown in Figure 2. Therefore, $36(3 \times 3 \times 4)$ experimental PVC pipes were used where each pipe was transplanted with two seedlings of rice (Oryza sativa. L).

Recommended amount of Urea (150 mg N/kg), Potassium phosphate $(100 \mathrm{mg} \mathrm{P} / \mathrm{kg})$ and Potassium sulfate $(130 \mathrm{mg} \mathrm{K} / \mathrm{kg})$ were applied based on soil test. Over $7 \mathrm{~d}$ period after transplanting, irrigation with $25 \mathrm{~mm}$ of water was applied to all treatments to make both soils and plant roots to be stable. The irrigation water regimes practiced in this study are expressed in Table 2.

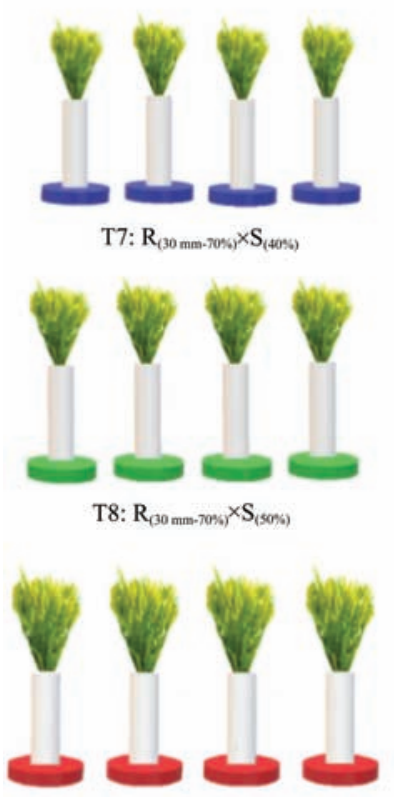

T9: $\mathbf{R}_{(30 \mathrm{~mm}-20 \times \mathrm{K})} \times \mathrm{S}_{(60 \mathrm{~m})}$

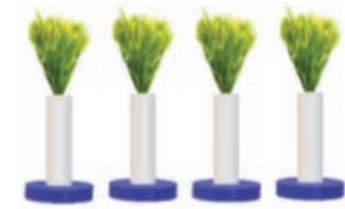

$\mathrm{T} 4: \mathbf{R}_{(00 \mathrm{~mm}-\mathrm{Nos})} \times \mathbf{S}_{(400 \mathrm{O})}$

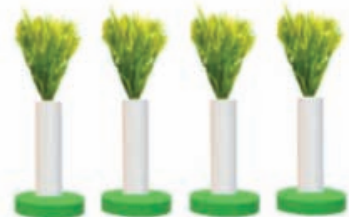

T5: $\mathbf{R}_{(30 \mathrm{~mm} \cdot 700 \mathrm{~s})} \times \mathbf{S}_{(50 \mathrm{~s})}$

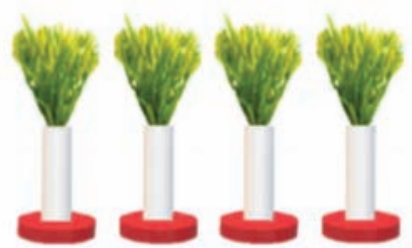

T6: $\mathrm{R}_{(30 \mathrm{~mm}-70 \mathrm{~s})} \times \mathrm{S}_{(00 \mathrm{~S})}$



$\mathrm{T} 2: \mathbf{R}_{(30 \mathrm{~mm}, 7006)} \times \mathbf{S}_{(5005)}$

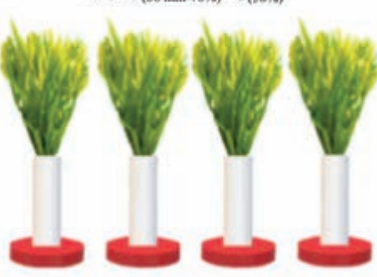

$\mathrm{T} 3: \mathbf{R}_{(30 \mathrm{~mm}-7005)} \times \mathbf{S}_{(00 \mathrm{~m})}$

Figure 2 Experimental design of the main treatments and sub-treatments

Table 2 Experimental design of controllable irrigation

\begin{tabular}{|c|c|c|c|c|c|c|c|c|}
\hline \multirow{2}{*}{ Clay $/ \%$} & \multirow{2}{*}{ Water regime } & \multirow{2}{*}{ Limit } & \multicolumn{6}{|c|}{ Irrigation quantity at different growth stages } \\
\hline & & & Recovery & Tillering & Booting & Flowering & Filling & Ripeness \\
\hline 40 & \multirow[b]{2}{*}{$\mathrm{R}_{(30 \mathrm{~mm}-100 \%)}$} & Upper mm & 30 & 30 & 30 & 30 & 30 & $10 \%$ \\
\hline $\begin{array}{l}50 \\
60\end{array}$ & & Lower \% & 100 & 100 & 100 & 100 & 100 & $10 \%$ \\
\hline 40 & \multirow{2}{*}{$\mathrm{R}_{(30 \mathrm{~mm}-90 \%)}$} & Upper mm & 30 & 30 & 30 & 30 & 30 & $10 \%$ \\
\hline $\begin{array}{l}50 \\
60\end{array}$ & & Lower \% & 90 & 90 & 90 & 100 & 90 & $10 \%$ \\
\hline 40 & \multirow[b]{2}{*}{$\mathrm{R}_{(30 \mathrm{~mm}-70 \%)}$} & Upper mm & 30 & 30 & 30 & 30 & 30 & $10 \%$ \\
\hline $\begin{array}{l}50 \\
60\end{array}$ & & Lower \% & 70 & 70 & 70 & 100 & 70 & $10 \%$ \\
\hline
\end{tabular}

Note: The upper limit of irrigation means that the soil was $100 \%$ saturated then flooded by $30 \mathrm{~mm}$. The lower limit of irrigation indicates the percentage of saturated moisture content of the soil after the disappearance of standing water.

\subsection{Data collection}

Soil moisture content and cracking intensity: With a previous knowledge of the weight of the empty pipe, filter layers and the dry soil, the moisture values were directly measured during the season by weighting the pipes with their contents on precision scales. The moisture values (\%) were calculated by the following equation:

Soil moisture content $=($ wet soil - dry soil $/$ dry soil $) \times 100$ 
Within each soil surface area in each pipe, the length $(\mathrm{cm})$, the depth $(\mathrm{cm})$ and the width $(\mathrm{cm})$ of each crack were recorded when the soil moisture content reached the low limit before irrigating water in each irrigation regime along the growing season. The measurements were conducted based on the procedure adopted by Bandyopadhyay et al. ${ }^{[20]}$. The volume $V\left(\mathrm{~cm}^{3}\right)$ of each crack was computed using the equation that assuming a triangular shape of the cracks $^{[34]}$.

$$
V=\sum 0.5 d \cdot w \cdot l
$$

where, $w$ is width of the crack, $\mathrm{cm}$; $d$ is depth of the crack, $\mathrm{cm} ; l$ is length of the part of the crack, cm; Cracks volumes were correlated with soil clay content and soil water content at the low limit for $\mathrm{R}_{(30 \mathrm{~mm}-100 \%)}, \mathrm{R}_{(30 \mathrm{~mm}-90 \%)}$ and $\mathrm{R}_{(30 \mathrm{~mm}-70 \%)}$.

Percolation, irrigation and evapotranspiration quantities: Percolation samples were monitored for $\mathrm{R}_{(30 \mathrm{~mm}-100 \%)}, \mathrm{R}_{(30 \mathrm{~mm}-90 \%)}$, and $\mathrm{R}_{(30 \mathrm{~mm}-70 \%)}$ after each irrigation along the growing season. Water samples were collected and volumes were measured. The cumulative percolation water volumes were determined and summed monthly and shown as total amounts (Table 4).

From each irrigation regime, irrigation water was submitted to $\mathrm{S}_{(40 \%)}, \mathrm{S}_{(50 \%)}$ and $\mathrm{S}_{(60 \%)}$ as the moisture content declined to the low limit. The amount of irrigation water was calculated due to the soil type as the following equation:

Irrigation water $(\mathrm{mm})=30 \mathrm{~mm}-(\%$ saturated moisture -

$\%$ actual moisture when watering) $\times$ soil dry weight $/ A$

where, $A=3.14(D / 2)^{2} ; D$ is the inner diameter of the tube, $\mathrm{m}$. The cumulative irrigation volumes were determined after each irrigation event, summed and shown as total amounts in Table 4.

The evapotranspiration was predicted by calculating the difference between the volume of irrigation water and the volume of percolation water. The cumulative evapotranspiration volumes were determined, summed and shown as a total amount in Table 4.

Growth indicators and yield parameters: From each pipe of each plot, data regarding the plant height, maximum number of tillers/pipe, number of panicles/pipe and panicle length were recorded within the growth stages of the plant. Stem length and root biomass were measured post harvesting. After harvest by hand cutting at the soil surface, plants of each pipe were oven dried at $70^{\circ} \mathrm{C}$ for $72 \mathrm{~h}$ and weighed. Grains yield and straw yield were determined based on moisture content of $13 \%-14 \%$. Harvest Index (\%) was calculated as the total grain biomass divided by the above-ground biomass at harvest. The roots were collected separately from each pipe by washing the soils carefully. The mass of the roots for the treatments were determined by drying the roots first in air and then oven-dried at $70^{\circ} \mathrm{C}$ for $48 \mathrm{~h}$.

Water use efficiency: Irrigation water productivity, IWP $\left(\mathrm{g} / \mathrm{m}^{3}\right)$ was determined as the ratio of the yield to the evapotranspiration during the irrigation season. Total water productivity TWP $\left(\mathrm{g} / \mathrm{m}^{3}\right)$ was calculated based on the ratio of the yield to the total water applied.

Statistical analysis: The IBM-SPSS statistical package version 19.0 was used to analyze the experimental data. Treatments were compared using the analysis of variance at $(p \leq 0.05)$ whereas their means were separated using Duncan's test at the same probability level.

\section{Results and discussion}

\subsection{Soil water content, soil clay content and cracks volume}

The soil water content in each plot was successfully controlled according to the design of irrigation regime. Relationship between soil moisture content as low limit, soil clay content, and cracking intensity is shown in Figure 3.



Figure 3 The relationship between soil water content, clay content and cracks volume

Crack volume was significantly correlated with the soil clay content, and soil water content at the low limit of irrigation regime practiced in this investigation (Table 3).

Table 3 Relationship between crack volume, soil clay content and soil water content

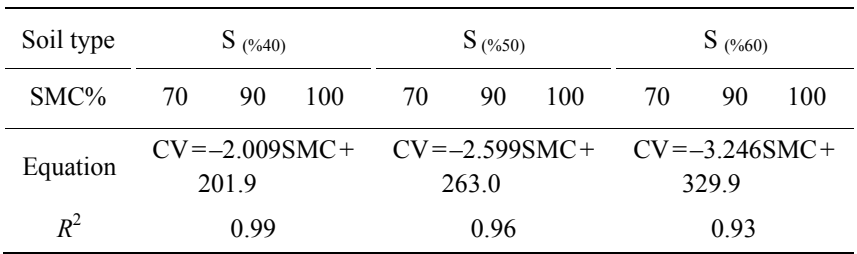

Note: $\mathrm{S}_{(40 \%)}, \mathrm{S}_{(50 \%)}$, and $\mathrm{S}_{(60 \%)}$ denote soil contain clay percentage of 40,50 and $60 \%$ respectively. SMC denote soil moisture content at the low limit for $\mathrm{R}_{(30 \mathrm{~mm}-100 \%)}, \mathrm{R}_{(30 \mathrm{~mm}-90 \%)}$ and $\mathrm{R}_{(30 \mathrm{~mm}-70 \%)}$. CV denote crack volume.

In $\mathrm{R}_{(30 \mathrm{~mm}-100 \%)}$ plot, soil cracks did not form regardless the clay content. When decreasing the soil moisture content to $90 \%$ in $\mathrm{R}_{(30 \mathrm{~mm}-90 \%)}$, cracks were developed and amounted, on average means of volumes, with $25.22 \mathrm{~cm}^{3}, 40.57 \mathrm{~cm}^{3}$ and $56.00 \mathrm{~cm}^{3}$ for $\mathrm{S}_{(40 \%)}, \mathrm{S}_{(50 \%)}$ and $\mathrm{S}_{(60 \%)}$ respectively. Further decrease the soil moisture content to $70 \%$ in $\mathrm{R}_{(30 \mathrm{~mm}-70 \%)}$ resulted in larger cracks' volumes of $62.47 \mathrm{~cm}^{3}, 79.46 \mathrm{~cm}^{3}$ and $100.23 \mathrm{~cm}^{3}$ for $\mathrm{S}_{(40 \%)}, \mathrm{S}_{(50 \%)}$ and $\mathrm{S}_{(60 \%)}$ respectively. In $\mathrm{R}_{(30 \mathrm{~mm}-100 \%)}$ plot, cracks were not created in all soils due to clay swelling since all soils were kept close to saturation. Soil cracking under $\mathrm{R}_{(30 \mathrm{~mm}-90 \%)}$ was attributed to the removal of water from within and between clay microstructures, while water evaporation at the soil surface, water uptake by plant roots and deeper drainage are the major reasons of water removal. The increase of cracks volume from $S_{(40 \%)}$ to $S_{(60 \%)}$ was due to the increase of swell-shrinkage potential. Similarly, soil cracking intensity and soil clay content were negatively correlated with soil moisture ${ }^{[35]}$. Also, growing rice in clayed soil enhanced the volume of cracks as soil water content was reduced ${ }^{[20]}$. The largest cracks' volumes under $\mathrm{R}_{(30 \mathrm{~mm}-70 \%)}$ was interpreted by most water evaporation at the soil surface, and most percolation water since fissures increase the soil surface and help water to penetrate to a more in-depth layer. As a consequence, growing rice in a soil with more clay content causes the soil to undergo a considerable amount of cracking. This result confirms the result of an earlier report that an increase in the volume of the cracks leads to a decrease in the soil moisture content ${ }^{[36]}$, and also another report that soil cracks geometry depends much upon soil water content dynamics ${ }^{[37]}$. The present results indicate the importance of the low limit of irrigation regime for rice crop cultivated in highly clayed soils during the growing season, also confirm that an 
increase in the soil cracking intensity (volume of cracks) was closely correlated with the irrigation regime and soil clay content $^{[35]}$.

\subsection{Water consumption}

Percolation water after each irrigation: Volumes of percolation water after each irrigation event are shown in Figure 4.

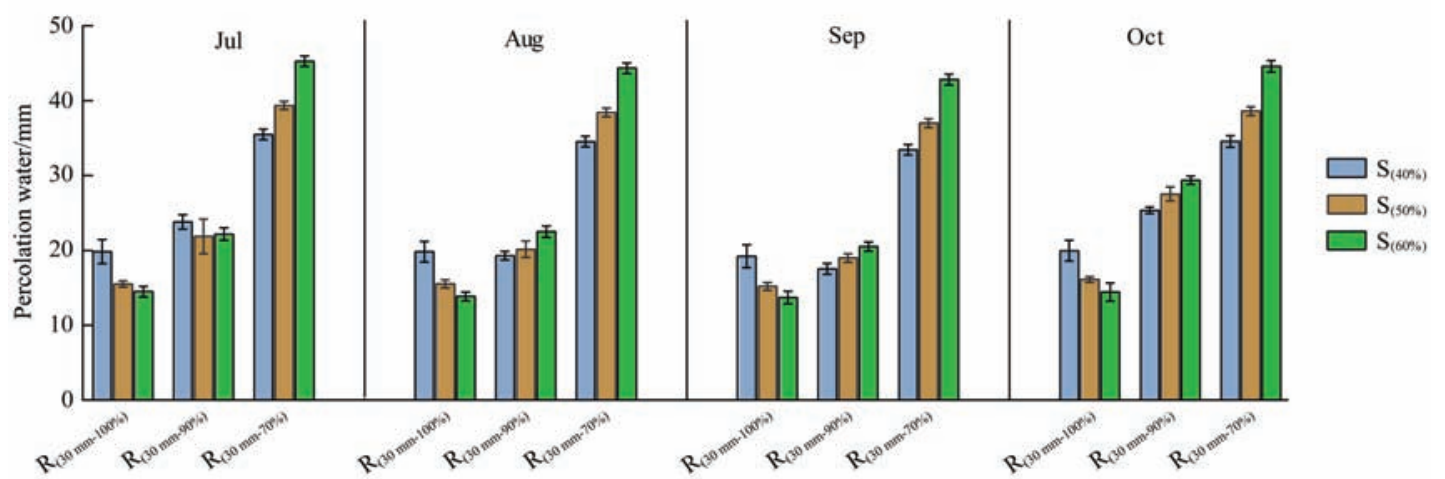

Figure 4 Percolation water after each irrigation event as affected by irrigation regime and soil type

Under $\mathrm{R}_{(30 \mathrm{~mm}-100 \%)}$ plot, the percolation rate was decreased with the increase of soil clay content. The highest amount of percolation water, as an average, was obtained with $\mathrm{S}_{(40 \%)}$ at $19.8 \mathrm{~mm}$ while the lowest amount of seepage water was recorded with $\mathrm{S}_{(60 \%)}$ at $14.3 \mathrm{~mm}$. The result indicated that the increase in clay content strengthen the soil capability of absorbing a great amount of water, causing the reduction in deeply discharge water after each irrigation event. In previous investigations, percolation losses were highly dependent on the hydrological properties of a given soil. For example, in a sandy loam soil in India, half of the total water input in rice field was lost by percolation ${ }^{[38]}$, while in swelling clayey California soils about $15 \%$ of applied water was lost via percolation and seepage ${ }^{[10]}$. Under $\mathrm{R}_{(30 \mathrm{~mm}-90 \%)}$ plot, when the soil moisture content reached $90 \%$ of saturation, the amount of percolation became complex due to soil cracking and depth of standing water. However, the average of the highest amount of percolation amount was recorded with $\mathrm{S}_{(60 \%)}$ at $23.7 \mathrm{~mm}$ while the lowest amount was recorded with $\mathrm{S}_{(40 \%)}$ at $21.5 \mathrm{~mm}$. It was noticeable that the amount of percolation water after each irrigation event overweighed the amount of percolation water under $\mathrm{R}_{(30 \mathrm{~mm}-100 \%)}$ in the order of $\mathrm{S}_{(60 \%)}, \mathrm{S}_{(50 \%)}$ and $\mathrm{S}_{(40 \%)}$. This was because cracked soil under $\mathrm{R}_{(30 \mathrm{~mm}-90 \%)}$ increasing the infiltration rate and the percolation rate, while soil under $\mathrm{R}_{(30 \mathrm{~mm}-100 \%)}$ did not crack. Also, standing water on soil surface under $R_{(30 \mathrm{~mm}-90 \%)}$ was higher than that under $\mathrm{R}_{(30 \mathrm{~mm}-100 \%)}$ since the upper limit of $\mathrm{R}_{(30 \mathrm{~mm}-90 \%)}$ was reached by applying a higher quantity of irrigation water. In $\mathrm{R}_{(30 \mathrm{~mm}-70 \%)}$, $\mathrm{S}_{(60 \%)}$ resulted in the highest amount of percolation water at $44.3 \mathrm{~mm}$ while $\mathrm{S}_{(40 \%)}$ resulted in the lowest amount of deeply discharge water at $34.5 \mathrm{~mm}$. Here, the extent of soil cracking and the depth of ponded water apparently affected the amount of seepage water after each irrigation event. This is because when the soil moisture content reached the low limit, the volume of cracks was significantly increased. Since the upper limit of $\mathrm{R}_{(30 \mathrm{~mm}-70 \%)}$ was reached by irrigating soil with $30 \%$ of soil saturation plus $30 \mathrm{~mm}$, much water was lost through soil cracks. Therefore, the highest quantity of water percolated after each irrigation was under $\mathrm{R}_{(30 \mathrm{~mm}-70 \%)}$ in the order of $\mathrm{S}_{(60 \%)}, \mathrm{S}_{(50 \%)}$ and $\mathrm{S}_{(40 \%)}$. Likewise, soil cracks caused higher percolation rates, therefore, the daily consumption of water in intermittent irrigated clay soil was higher than in flooding irrigated soil ${ }^{[19]}$. Moreover, soil desiccation increased water percolation as the percolation rate was affected by the extent of soil cracking and the depth of ponded water in rewetting phase ${ }^{[39,40]}$. Furthermore, the rate of water percolation in paddy fields was described by the hydraulic head and the hydrological properties of the soil ${ }^{[41]}$.

Accumulative percolation water: Irrigation regime showed a significant effect on the total amount of percolation water at the level of $5 \% . \quad \mathrm{R}_{(30 \mathrm{~mm}-100 \%)}$ resulted in the highest value of total percolation water $(1275.6 \mathrm{~mm})$ while the lowest amount was recorded under $\mathrm{R}_{(30 \mathrm{~mm}-90 \%)}(824.2 \mathrm{~mm})$. Also, the total amount of seepage water under $\mathrm{R}_{(30 \mathrm{~mm}-70 \%)}$ was higher than that under

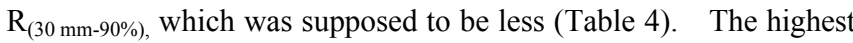
values of total percolation water in $\mathrm{R}_{(30 \mathrm{~mm}-100 \%)}$ was attributed to the increase in irrigation events, increased the total amount of percolation water by $35.4 \%$ and $21.2 \%$ compared to $\mathrm{R}_{(30 \mathrm{~mm}-90 \%)}$ and $\mathrm{R}_{(30 \mathrm{~mm}-70 \%)}$ respectively. The $21.9 \%$ increase in total percolation water under $\mathrm{R}_{(30 \mathrm{~mm}-70 \%)}$ in comparison to $\mathrm{R}_{(30 \mathrm{~mm}-90 \%)}$ was attributed to the increase in seepage water after each irrigation event, which is due to a considerable amount of soil cracking that accelerated the total amount of percolation water.

Table 4 Total amount of irrigation (I mm), percolation (P mm) and Evapotranspiration (ET $\mathrm{mm}$ ) for different treatments

\begin{tabular}{|c|c|c|c|c|}
\hline Water use & $\begin{array}{l}\text { Total } \\
\text { irrigation } \\
\text { water }\end{array}$ & $\begin{array}{l}\text { Total } \\
\text { percolation } \\
\text { water }\end{array}$ & $\begin{array}{c}\text { Total } \\
\text { evapotranspiration } \\
\text { water }\end{array}$ & $\begin{array}{l}\text { Irrigations } \\
\text { number }\end{array}$ \\
\hline \multicolumn{5}{|c|}{ Regime (R) } \\
\hline $\mathrm{R}_{(30 \mathrm{~mm}-100 \%)}$ & $2035.3^{\mathrm{a}}$ & $1275.6^{\mathrm{a}}$ & $759.7^{\mathrm{a}}$ & $74.8^{\mathrm{a}}$ \\
\hline $\mathrm{R}_{(30 \mathrm{~mm}-90 \%)}$ & $1472.2^{\mathrm{c}}$ & $824.2^{\mathrm{c}}$ & $648.3^{\mathrm{b}}$ & $39^{\mathrm{b}}$ \\
\hline $\mathrm{R}_{(30 \mathrm{~mm}-70 \%)}$ & $1649.6^{\mathrm{b}}$ & $1005^{\mathrm{b}}$ & $644.9^{\mathrm{b}}$ & $26^{\mathrm{c}}$ \\
\hline$p$-value & 0.00 & 0.00 & 0.00 & 0.00 \\
\hline \multicolumn{5}{|c|}{ Soil type (S) } \\
\hline $\mathrm{S}_{(40 \%)}$ & $1774.9^{\mathrm{a}}$ & $1063.4^{\mathrm{a}}$ & $711.5^{\mathrm{a}}$ & $47.6^{\mathrm{a}}$ \\
\hline $\mathrm{S}_{(50 \%)}$ & $1673.7^{\mathrm{a}}$ & $1002.8^{\mathrm{a}}$ & $691.3^{\mathrm{a}}$ & $47.6^{\mathrm{a}}$ \\
\hline $\mathrm{S}_{(60 \%)}$ & $1688.7^{\mathrm{a}}$ & $1038.7^{\mathrm{a}}$ & $650.1^{\mathrm{a}}$ & $44.4^{\mathrm{a}}$ \\
\hline$p$-value & 0.14 & 0.07 & 0.08 & 0.38 \\
\hline \multicolumn{5}{|c|}{ Interaction $(\mathrm{R} \times \mathrm{S})$} \\
\hline$p$-value & 0.08 & 0.29 & 0.37 & 0.42 \\
\hline
\end{tabular}

Note: In the column, averages followed by the common letter (s) are not significantly different at level of $p \leq 0.05$ according to Duncan's Multiple Range Test. $\quad \mathrm{ET}=$ evapotranspiration $(\mathrm{mm}), \mathrm{I}=$ irrigation $(\mathrm{mm}), \mathrm{P}=$ percolation $(\mathrm{mm})$. ET $(\mathrm{mm})=\mathrm{I}(\mathrm{mm})-\mathrm{P}(\mathrm{mm})$.

Frequency and quantity of irrigation input: At each irrigation event, the quantities of water applied to all soils were recorded as "30 mm every day", "10\% saturation recharge plus $30 \mathrm{~mm}$ every 2 days" and " $30 \%$ as water recharge plus $30 \mathrm{~mm}$ every 3 days" for $\mathrm{R}_{(30 \mathrm{~mm}-100 \%)}, \mathrm{R}_{(30 \mathrm{~mm}-90 \%)}$ and $\mathrm{R}_{(30 \mathrm{~mm}-70 \%)}$, respectively (Figure 5). 78,39 and 26 irrigations were applied to all soils under $\mathrm{R}_{(30 \mathrm{~mm}-100 \%)}$, $\mathrm{R}_{(30 \mathrm{~mm}-90 \%)}$ and $\mathrm{R}_{(30 \mathrm{~mm}-70 \%)}$ respectively during the growing season. 


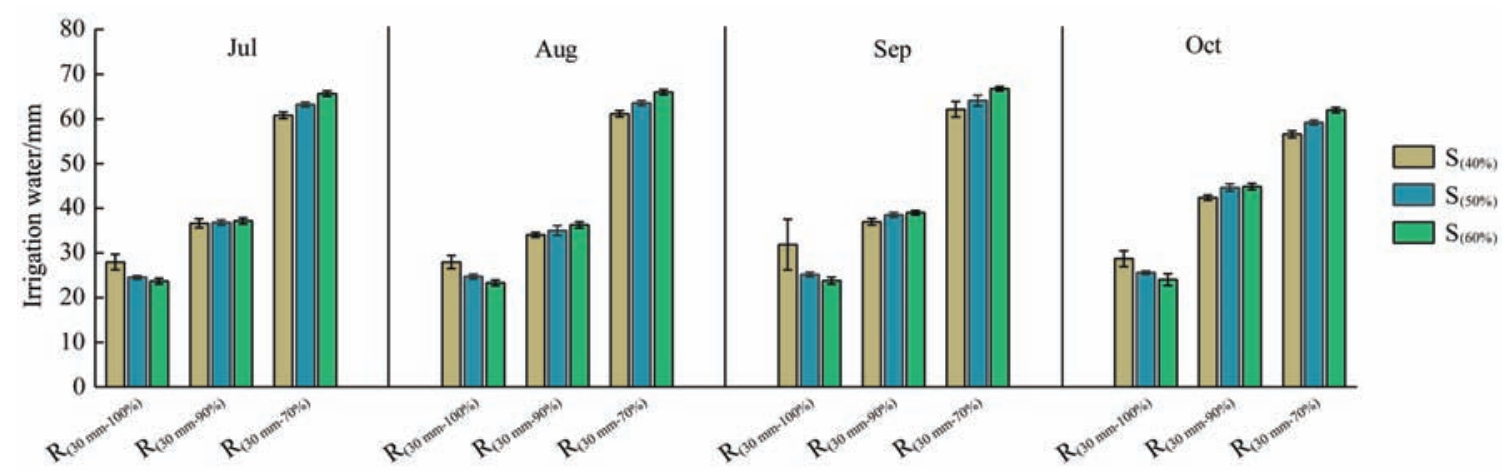

Figure 5 Volumes of water at each irrigation event due to irrigation regime and soil clay content

The number of irrigations was significantly affected by the method of watering at the 0.05 level (Table 4). The timing of irrigation was dependent on the soil moisture content at the low limit hypothesized for each regime practiced in this investigation. Soils under $\mathrm{R}_{(30 \mathrm{~mm}-100 \%)}$ reached the low limit 1-day after irrigation due to water percolation and evapotranspiration. The amount of irrigation water applied to all soils was around $30 \mathrm{~mm}$ to reach the upper limit since all soils were approximately saturated after the gradually decreased of ponding water. Therefore, 78 irrigations were performed in $\mathrm{R}_{(30 \mathrm{~mm}-100 \%)}$. For $\mathrm{R}_{(30 \mathrm{~mm}-90 \%)}$ plot, soils required two days to reduce soil moisture content to $10 \%$ below the saturation. Thus, the irrigation was performed once every two days to reach the upper limit every two days, resulting in 39 irrigations along the growing season. In $\mathrm{R}_{(30 \mathrm{~mm}-70 \%)}$, it takes three days to decrease soil water content to $30 \%$ below saturation although the disappearance of standing water was enhanced by soil desiccation. Consequently, 26 irrigation events were applied to soils for reaching the upper limit. The difference in water consumption, at each irrigation event, should be mainly from the difference between the low limit of irrigation regimes practiced in this study, while soil cracking, standing water depth, evapotranspiration, and percolation rate also could be reasons for such difference. Therein, percolation of water was increased with a large depth of ponding water. Cracks were also the motivation for a considerable increase in the irrigation water inputs at the time of irrigation.

Total irrigation input: The total amount of irrigation water was significantly affected by irrigation regime at the 0.05 level (Table 4). The amount of irrigation water was lower under $R_{(30 \mathrm{~mm}-90 \%)}$ and $\mathrm{R}_{(30 \mathrm{~mm}-70 \%)}$ compared to $\mathrm{R}_{(30 \mathrm{~mm}-100 \%)}$ because $\mathrm{R}_{(30 \mathrm{~mm}-90 \%)}$ and $\mathrm{R}_{(30 \mathrm{~mm}-70 \%)}$ decreased the intervals of irrigation and consequently decrease the total amount of water input. In contrary, the increase in irrigation intervals resulted in higher losses of water ${ }^{[41]}$, which could be a reason why the total water consumption in $\mathrm{R}_{(30 \mathrm{~mm}-100 \%)}$ plots was higher than that in $\mathrm{R}_{(30 \mathrm{~mm}-90 \%)}$ and $\mathrm{R}_{(30 \mathrm{~mm}-70 \%)}$. Likewise, growing rice in AWD systems reduced total water inputs by around $15 \%-30 \%$ compared to the conventional irrigation ${ }^{[12,9]}$. It was surprising that $\mathrm{R}_{(30 \mathrm{~mm}-70 \%)}$ consumed more water than $\mathrm{R}_{(30 \mathrm{~mm}-90 \%)}$, owing to the increase in percolation rate caused by the great amount of soil cracking as well as the highest depth of standing water on the soil surface in $\mathrm{R}_{(30 \mathrm{~mm}-70 \%)}$. Accordingly, a considerable amount of soil cracking with a larger amount of irrigation water for reaching the upper limit (higher depth of standing water) under $\mathrm{R}_{(30 \mathrm{~mm}-70 \%)}$ than that under $\mathrm{R}_{(30 \mathrm{~mm}-90 \%)}$ resulted in a greater amount of water loss, which was hypothesized to be less. As a result, greater soil cracking and higher standing water results in immediate water percolation and more water consumption, although irrigation intervals was reduced in term of this experiment.

Total evapotranspiration: Total evapotranspiration is presented in Table 4. Statistically, only irrigation regime showed significant influence on the total amount of evapotranspiration. $R_{(30 \mathrm{~mm}-100 \%)}$ resulted in the highest values of total evapotranspiration $(759.7 \mathrm{~mm})$ and the lowest amount was recorded under $\mathrm{R}_{(30 \mathrm{~mm}-70 \%)}(644.9 \mathrm{~mm})$, while this lowest amount had no significant difference compared to $\mathrm{R}_{(30 \mathrm{~mm}-90 \%)} \quad(648.3 \mathrm{~mm})$. The highest value of total evapotranspiration in $\mathrm{R}_{(30 \mathrm{~mm}-100 \%)}$ was attributed to the best growth of the plant, as well as the increase in irrigation events. $\mathrm{R}_{(30 \mathrm{~mm}-70 \%)}$ resulted in the lowest value of total irrigations. Nevertheless, the approximate values of total evapotranspiration under $\mathrm{R}_{(30 \mathrm{~mm}-90 \%)}$ and $\mathrm{R}_{(30 \mathrm{~mm}-70 \%)}$ indicates that cracks could serve as secondary evaporation plates ${ }^{[22]}$ to increase the total evapotranspiration under $\mathrm{R}_{(30 \mathrm{~mm}-70 \%)}$.

\subsection{Plant growth indicators}

Analysis of variance revealed that there were significant differences $(p \leq 0.05)$ among treatments in all growth indicators as shown in Figure 6.

The effect of irrigation regime on plant growth was significant at $5 \%$ level. The comparison of the mean values showed that the highest and the lowest of plant height $(72.15-55.55 \mathrm{~cm})$, the maximum number of tillers (38.00-28.25 tiller/pipe), panicles number (31.92-18.83 panicle/pipe), panicle length (14.77$10.10 \mathrm{~cm})$, root biomass (4.45-1.69 g/pipe) and stem length $(58.08-46.15 \mathrm{~cm})$ were recognized in $\mathrm{R}_{(30 \mathrm{~mm}-100 \%)}$ and $\mathrm{R}_{(30 \mathrm{~mm}-70 \%)}$ respectively. Clay proportion of soil significantly affected plant development at 5\% level. The greatest mean values of plant height $(73.11 \mathrm{~cm})$, the maximum number of tillers $(39.75$ tiller/pipe), panicles number (32.33 panicle/pipe), panicle length $(14.01 \mathrm{~cm})$, root biomass $(4.33 \mathrm{~g} / \mathrm{pipe})$ and stem length $(59.79 \mathrm{~cm})$ were obtained with $\mathrm{S}_{(60 \%)}$ while the lowest values $(56.71 \mathrm{~cm})$, (27.58 tiller/pipe), (19.92 panicle/pipe), (11.87 cm), (2.23 g/pipe) and $(45.53 \mathrm{~cm})$ were found in $\mathrm{S}_{(40 \%)}$ (Table 5). The interaction of irrigation regime and soil clay content had no significant differences in rice growth parameters except for panicles number and root biomass at 5\% level in this study. The greatest values of panicles number (40.75 panicles/pipe) and root biomass $\left(6.15 \mathrm{~g} /\right.$ pipe) were recorded under the combination $\mathrm{R}_{(30 \mathrm{~mm}-100 \%)}$ $\mathrm{S}_{(60 \%)}$. However, the lowest values $(15.5$ panicles/pipe, $1.044 \mathrm{~g} /$ pipe) of these indicators were found under the combination $\mathrm{R}_{(30 \mathrm{~mm}-70 \%)} \mathrm{S}_{(40 \%)}$ (Figure 6).

Plant height: Plant height in this experiment indicates the vigor of rice plant, which was directly proportional to development of root system and availability of water and nutrients in soils. The highest plant height was recorded at $\mathrm{R}_{(30 \mathrm{~mm}-100 \%)}$, which may be 
because that keeping soil water content at saturation and reflooding helped soils to hold more water including more nutrients by swelling, provided a typical medium for the plant to be fully grown. Conversely, decreasing soil moisture content $30 \%$ below the saturation and reflooding under $\mathrm{R}_{(30 \mathrm{~mm}-70 \%)}$ resulted in soil cracking and more leaching of water and nutrients, significantly interrupted plant growth regarding the decrease in plant height. Lu et al. ${ }^{[19]}$ realized under different irrigation regimes, plant height decreased from continuous flooding to intermittent irrigation. They also reported that decrease of soil moisture content under saving-water irrigation results more soil desiccation, while no cracks under continues submerge was discovered. In addition, Dou et al. ${ }^{[42]}$ reported significant differences in plant height among varieties of rice grown under different irrigation regimes. They found that continuous flooding regime had higher plant height during the entire growing period as compared with aerobic water regimes. Also, Styger. ${ }^{[43]}$ revealed that rice plant height was decreased with increasing water stress. Furthermore, Mostafazadeh-Fard et al. ${ }^{[44]}$ studied the effect of irrigation water management on the yield of rice in cracked soils, recording the reduction in plant height with the increased in cracks width from $3-4 \mathrm{~mm}$ to $1.5 \mathrm{~cm}$. These findings of plant height under different soils were consistent with the increase in clay proportions. The increase of clay content from $40 \%$ to $60 \%$ increased the ability of soil to swell when it irrigated, comprising more water and nutrients in which plant was full grown, thus consistently increased plant height by $22.43 \%$.
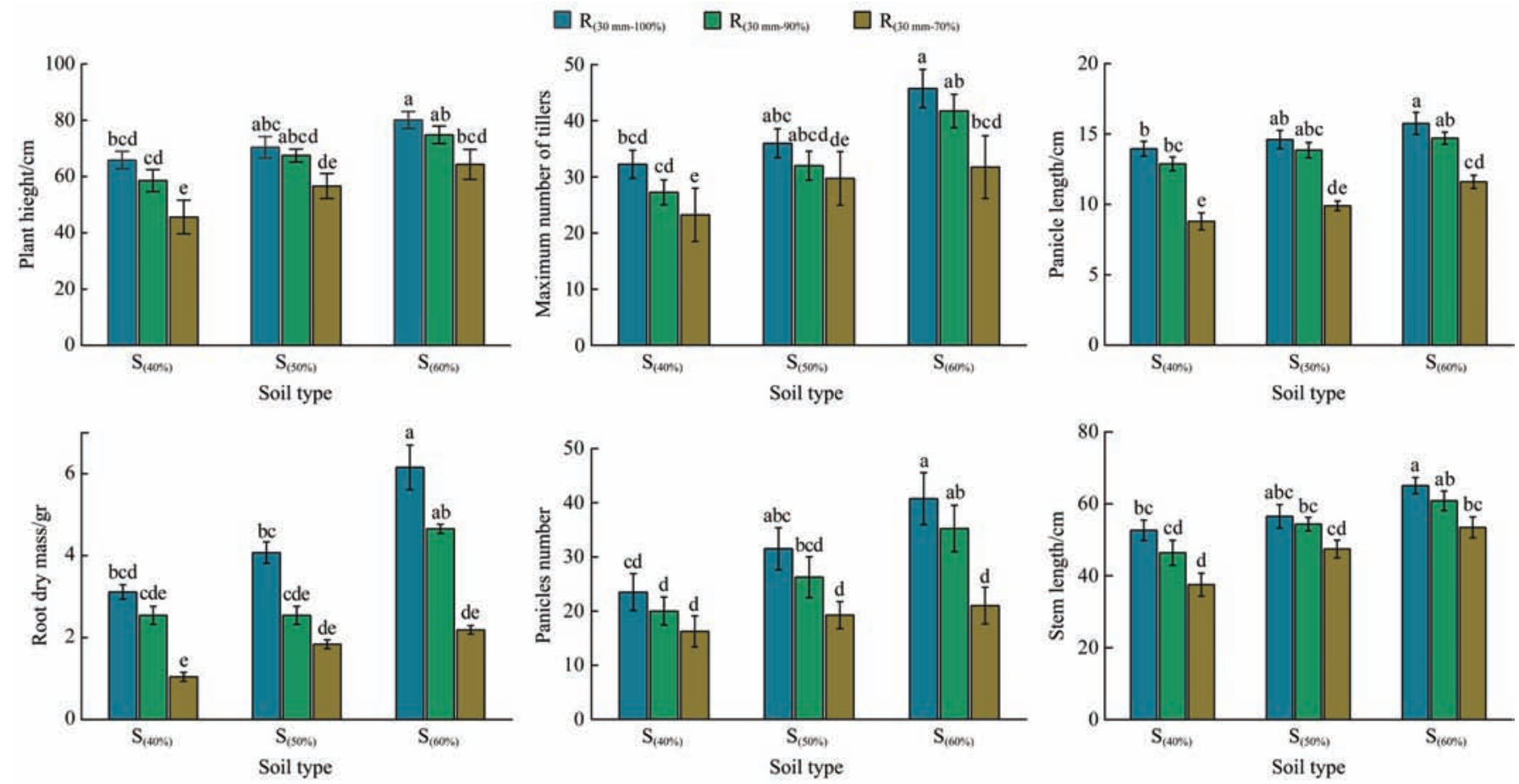

Figure 6 Influence of irrigation method and soil clay content on growth components of rice

Table 5 Growth components of rice as affected by irrigation regime and soil clay content

\begin{tabular}{|c|c|c|c|c|c|c|}
\hline \multirow{2}{*}{$\begin{array}{c}\text { Factor } \\
\text { Regime (R) }\end{array}$} & \multicolumn{6}{|c|}{ Growth indicator } \\
\hline & $\begin{array}{l}\text { Plant } \\
\text { Height } \\
\text { /cm }\end{array}$ & $\begin{array}{l}\text { Tillers } \\
\text { number } \\
\text { /pipe }\end{array}$ & $\begin{array}{l}\text { Panicles } \\
\text { number } \\
\text { /pipe }\end{array}$ & $\begin{array}{c}\text { Panicle } \\
\text { length } \\
/ \mathrm{cm}\end{array}$ & $\begin{array}{l}\text { Stem } \\
\text { length } \\
/ \mathrm{cm}\end{array}$ & $\begin{array}{c}\text { Root } \\
\text { biomass } \\
\text { /g.pipe }{ }^{-1}\end{array}$ \\
\hline $\mathrm{R}_{(30 \mathrm{~mm}-100 \%)}$ & $72.15^{\mathrm{a}}$ & $38.00^{\mathrm{a}}$ & $31.92^{\mathrm{a}}$ & $14.77^{\mathrm{a}}$ & $58.08^{\mathrm{a}}$ & $4.45^{\mathrm{a}}$ \\
\hline $\mathrm{R}_{(30 \mathrm{~mm}-90 \%)}$ & $66.98^{\mathrm{b}}$ & $33.67^{\mathrm{b}}$ & $27.17^{\mathrm{b}}$ & $13.81^{\mathrm{b}}$ & $53.87^{\mathrm{b}}$ & $3.63^{\mathrm{b}}$ \\
\hline $\mathrm{R}_{(30 \mathrm{~mm}-70 \%)}$ & $55.55^{\mathrm{c}}$ & $28.25^{\mathrm{c}}$ & $18.83^{\mathrm{c}}$ & $10.10^{\mathrm{c}}$ & $46.15^{\mathrm{c}}$ & $1.69^{\mathrm{c}}$ \\
\hline$p$-value & 0 & 0 & 0 & 0 & 0 & 0 \\
\hline \multicolumn{7}{|c|}{ Soil type (S) } \\
\hline $\mathrm{S}_{(40 \%)}$ & $56.71^{\mathrm{c}}$ & $27.58^{\mathrm{c}}$ & $19.92^{\mathrm{c}}$ & $11.87^{\mathrm{c}}$ & $45.53^{\mathrm{c}}$ & $2.23^{\mathrm{c}}$ \\
\hline $\mathrm{S}_{(50 \%)}$ & $64.86^{\mathrm{b}}$ & $32.58^{\mathrm{b}}$ & $25.67^{\mathrm{b}}$ & $12.78^{\mathrm{b}}$ & $52.78^{\mathrm{b}}$ & $3.20^{\mathrm{b}}$ \\
\hline $\mathrm{S}_{(60 \%)}$ & $73.11^{\mathrm{a}}$ & $39.75^{\mathrm{a}}$ & $32.33^{\mathrm{a}}$ & $14.01^{\mathrm{a}}$ & $59.79^{\mathrm{a}}$ & $4.33^{\mathrm{a}}$ \\
\hline$p$-value & 0 & 0 & 0 & 0 & 0 & 0 \\
\hline \multicolumn{7}{|c|}{ Interaction $(\mathrm{R} \times \mathrm{S})$} \\
\hline$p$-value & 0.38 & 0.6 & 0.01 & 0.31 & 0.33 & 0 \\
\hline
\end{tabular}

Note: In the column, averages followed by the common letter (s) are not significantly different at the level of $p \leq 0.05$ according to Duncan's Multiple Range Test. $\mathrm{R} \times \mathrm{S}$ means the interaction between irrigation regime $(\mathrm{R})$ and soil type (S).
The maximum number of tillers: The enhancement in the number of tillers under $\mathrm{R}_{(30 \mathrm{~mm}-100 \%)}$ was caused by the availability of plant nutrients and water under an anaerobic condition which prevented the formation of cracks. Moreover, the unfavorable nutrient regime for several plant nutrients was created under non-flooded condition ${ }^{[45]}$. The reduction in the number of tillers by $25.65 \%$ during $\mathrm{R}_{(30 \mathrm{~mm}-70 \%)}$ was mainly attributed to the limited supply of water within the root zones and nutrient losses due to soil cracking that inhibited tillering and growth of tiller buds. This result is consistent with the result of the earlier investigation, recording a higher number of tillers under flooding irrigation (soil created no cracks) than three types of intermittent irrigation (soil developed fractures $)^{[19]}$. Also, the continuous flooding irrigation produced more tillers of rice than intermittent irrigation ${ }^{[42,46]}$. Under clay content of $60 \%$, soils in this experiment showed significant differences in the number of tillers which was probably linked to overall soil fertility as well as the availability of plant nutrients and water. Through a previous study, soil texture apparently influenced the number of tiller per plant where a higher number of tillers was realized in clay-textured soil than in loam-textured soil ${ }^{[42]}$.

The number of panicles: Sufficient amount of water offered by $\mathrm{R}_{(30 \mathrm{~mm}-100 \%)}$ raised the number of panicles by $58.98 \%$ compared to 
$\mathrm{R}_{(30 \mathrm{~mm}-70 \%)}$. Such result indicated that panicles number of rice under flooding conditions quantified higher than in aerobic soil conditions wherein the latter soil was cracked ${ }^{[42]}$. Difference on soil type also creates differences on nutrient supply or nutrient uptake of rice, which affected rice development and panicles number. It was previously stated that rice panicle number was significantly increased from loam and sandy-textured soil to clay-textured soil ${ }^{[42,47]}$, and correspondently the tillers number in $\mathrm{S}_{(40 \%)}$ is $38.38 \%$ less than $\mathrm{S}_{(60 \%)}$. The differences occurred on the panicles number were caused by the ability of $S_{(60 \%)}$ to trap more water including nutrients than $\mathrm{S}_{(40 \%)}$ under $\mathrm{R}_{(30 \mathrm{~mm}-100 \%)}$. Under $\mathrm{R}_{(30 \mathrm{~mm}-70 \%)}$, shrunken soilloses more nutrients, in which $61.96 \%$ reduction in panicles number was happened (Figure 6). The differences in soil texture and irrigation regime affected water and nutrient supply or uptake of rice, further impacted rice development and panicles number ${ }^{[42]}$.

Panicle length: The length of the rice panicle decides the number of grains it can hold ${ }^{[48,49]}$ and consequently rice yield ${ }^{[50]}$. In this experiment, panicle length under $\mathrm{R}_{(30 \mathrm{~mm}-100 \%)}$ was $46.23 \%$ more than that under $\mathrm{R}_{(30 \mathrm{~mm}-70 \%)}$, and panicle length increased by $18.02 \%$ with the increase of clay content from $40 \%$ to $60 \%$. Such increase was correlated to water and nutrient availability, which could affect the trait of panicles and increase the performance of their length. The better vegetative growth under $R_{(30 \mathrm{~mm}-100 \%)}$ played an important role in higher yield and better grain filling in rice through efficient transport of water and nutrients from the leaves and stems. Whereas, the shortest panicle under $\mathrm{R}_{(30 \mathrm{~mm}-70 \%)}$ due to soil shrinkage resluted in more loss of nutrients and water from the soil profile. Correspondingly, increase in spike length of rice was observed under increased nutrient availability ${ }^{[51]}$, proved the idea that spike length was significantly affected by soil texture $^{[42]}$.

Root biomass: As rice plants are very sensitive to soil moisture decrease, roots response to soil moisture variation for flooding and saving irrigation regimes. Moreover, high root activity with great root dry matter indicates strong water and nutrient uptake which support high biomass production. Therefore, root biomass was used as an indicator of vigorous root growth in this experiment. The high amount root biomass under $\mathrm{R}_{(30 \mathrm{~mm}-100 \%)}$ referred the vigorous root system. This observation indicated better growth condition requires more water and nutrients since rice is semi-aquatic plant and its roots prefer the conditions with more available water content. In opposition, a significant amount of fractures under $\mathrm{R}_{(30 \mathrm{~mm}-70 \%)}$ could affect the development of roots and overall plant growth Therefore, in this study, superior root activity had higher total dry biomass. Correspondingly, a positive correlation between root growth and total biomass production of rice was revealed ${ }^{[52]}$. Increasing clay content from $40 \%$ to $60 \%$ strengthen soil's ability to swell, capture water and nutrients, allow semi-aquatic plants to develop a stronger underground system in addition to easier penetration of root. The present results supportsearlier reports that growth and dry biomass of rice root under clay loam soil were better than in sandy loam soil due to the nutrient and water availability ${ }^{[53]}$. Also, soil physical properties were a more fundamental constraint on root growth than soil water availability during the aerobic period of rice irrigation ${ }^{[54]}$. The reason for differences in root biomass under the interaction between irrigation method and soil type was explained by more accessible water with more available nutrients due to soil swelling, and vigorous root was developed under the combination $\mathrm{R}_{(30 \mathrm{~mm}-100 \%)} \mathrm{S}_{(60 \%)}$. Whereas, soil shrinkage resulted in further losses of water and nutrients, and soil cracks caused physical damage to crop roots ${ }^{[55]}$. In this case, root growth was restricted under the combination $\mathrm{R}_{(30 \mathrm{~mm}-70 \%)} \mathrm{S}_{(40 \%)}$.

Stem length: The result of stem length referred the relationship root-to-shoot growths since $\mathrm{R}_{(30 \mathrm{~mm}-100 \%)}$ resulted in $21.87 \%$ greater root biomass than that found under $\mathrm{R}_{(30 \mathrm{~mm}-70 \%)}$ in the present study. Likewise, correlations between roots and shoot growth in rice were previously mentioned ${ }^{[56]}$, and stem elongation was significantly reduced under the intermittent irrigation regime compared to flooding irrigation regime associated with non-cracked soil ${ }^{[19]}$. The decrease in the stem length under intermittent irrigation water regime compared to continuous flooding was attributed to the increased soil water stress ${ }^{[57]}$. Furthermore, in response to flooding environment, some rice cultivars could accelerate culm elongation to an unbelievable rice stem elongation rates of up to $25 \mathrm{~cm}$ per day ${ }^{[58]}$. Conversely, drought reduced elongation as well as expansion growth ${ }^{[59]}$ and shoot length ${ }^{[60]}$ of rice. The stem is the main channel for nutrient transport and starch storage. Therefore; the increase in stem length with the increase in clay content of the soil indicated higher availability of nutrients and water offered by $\mathrm{S}_{(60 \%)}$. $\quad \mathrm{S}_{(40 \%)}$ decreased the development of root system by $31.32 \%$ due to the reduction in soil water content as well as available nutrients, also caused the reduction in stem length.

\subsection{Yield indicators}

The analysis of variance presented significant differences in total biomass, grain yield, and harvest index of rice in all treatments as shown in Figure 7 below.
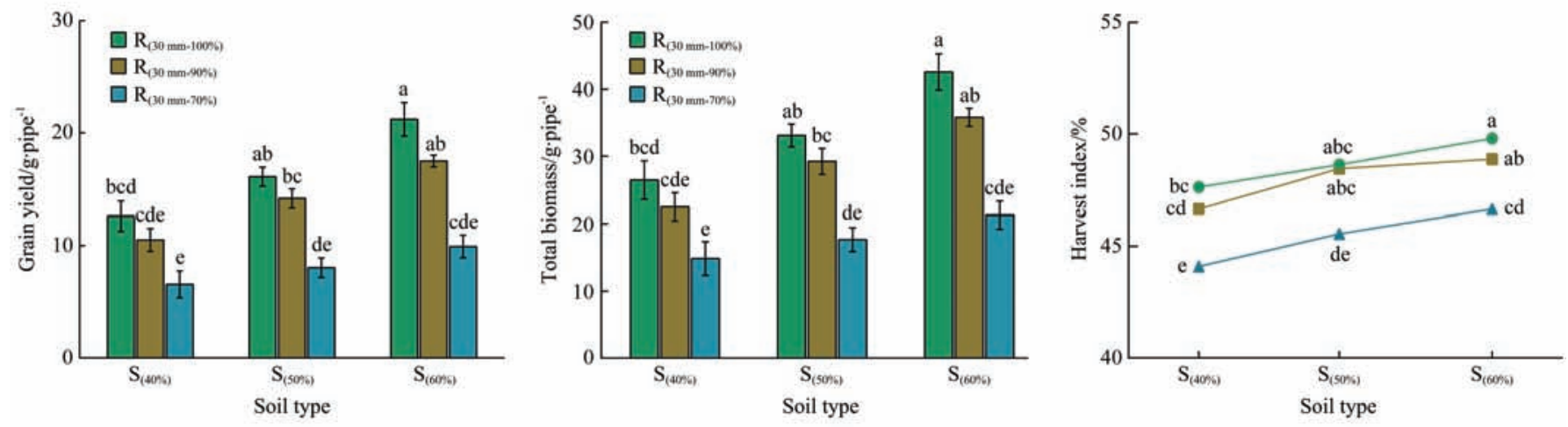

Figure 7 Yield indicators of rice as affected by water regime and soil clay content

The effect of irrigation regime as well as soil clay content on total biomass, grain yield, and harvest index is significant at 0.05 level. Also, the effect of their interaction on yield indicators is significant at 0.05 level except for harvest index (Table 6). In different regimes, comparison of average values indicated that $\mathrm{R}_{(30 \mathrm{~mm}-100 \%)}$ harvested the highest values while $\mathrm{R}_{(30 \mathrm{~mm}-70 \%)}$ yielded 
the lowest values of total dry mass, grain yield, and harvest index as (34.04-17.92 g/pipe), (16.63-8.18 g/pipe) and (48.68\%-45.42\%) respectively. Among soils, the highest total dry mass (33.22 g/pipe), grain yields (16.21 g/pipe), and harvest index (48.43\%) were found in the $\mathrm{S}_{(60 \%)}$ and the lowest total dry mass (21.27 g/pipe), grain yield (9.89 g/pipe), and harvest index (46.13\%) were attributed to the $\mathrm{S}_{(40 \%)}$. Due to the interaction, $\mathrm{R}_{(30 \mathrm{~mm}-100 \%)}$ $\mathrm{S}_{(60 \%)}$ treatment harvested the highest total biomass (42.56 g/pipe) and grain yield $(21.20 \mathrm{~g} /$ pipe $)$ while $\mathrm{R}_{(30 \mathrm{~mm}-70 \%)} \mathrm{S}_{(40 \%)}$ treatment yielded the lowest in total dry mass (14.85 g/pipe) and grain yield (6.56 g/pipe) of rice (Figure 7).

Total biomass: The increase by $89.95 \%$ in total above-ground dry weight in $\mathrm{R}_{(30 \mathrm{~mm}-100 \%)}$ was attributed to the better growth condition. More available water and nutrients encouraged more emergences of tillers and leaves and overall plant growth. Reducing soil content to $80 \%$ saturation in different stages of rice growth not only harms the rice production but also decreases its quality. In addition, the reductions in tillers and leaves number due to water stress and greater soil cracking was the reason for the reduction in dry matter and grain yield in the intermittent irrigation regimes ${ }^{[8]}$. Equally, the decrease in dry matter production and grain yield in rice was caused by little soil moisture decreased ${ }^{[41,61]}$. The total above-ground mass increased by $56.18 \%$ when the clay content increased from $40 \%$ to $60 \%$. The increase of clay content resulted in a more active surface area that trapped water and nutrient efficiently, thus could provide more water and nutrients needed by the rice plant promoting the growth of tillers, leaves, stems, panicles, and spikelets, therefore increase the total biological mass. Tsubo et al. ${ }^{[62]}$ recorded greater biomass accumulation of rice grown in higher clay content soils than those grown in lower clay content soils. Also, Dou et al. ${ }^{[42]}$ found the highly significant impact of soil textures on shoot biomass. They also reported significant variations in biological mass of rice as affected by soil texture. The results of total biological mass due to the interaction between irrigation regime and soil clay content signified the tremendous impact of soil clay content on rice cultivation under various irrigation regimes. The increase in water contents in finer textured soils enhanced the total biological yield of rice due to clay swelling kept water and nutrients, enhanced the vegetative growth of plant increasing straw yield, Together with yield attributing characters, it improved the total biological yield as shown in the interaction $\mathrm{R}_{(30 \mathrm{~mm}-100 \%)} \mathrm{S}_{(60 \%)}$ Figure 7. However, the decrease in water content in the high clayed soil as in the interaction $\mathrm{R}_{(30 \mathrm{~mm}-70 \%)}$ $\mathrm{S}_{(40 \%)}$ deteriorated total biomass due to clay shrinkage leached out water and nutrients needed for rice. The present result conforms with a previous result recording significant differences in total biomass of rice under the combination of irrigation regime and soil texture type ${ }^{[42]}$.

Grain yield: Contrary to $\mathrm{R}_{(30 \mathrm{~mm}-100 \%)}$, the decrease by $50.81 \%$ in grains yield in $\mathrm{R}_{(30 \mathrm{~mm}-70 \%)}$ was caused by water stress and soil desiccation. These two factors increased the losses of water and nutrients, which reduced the effective tillers and panicle development during the earlier stage and affected the reproductive physiology by interfering with pollination, fertilization, and grain filling during the later stage. The reason for grain yield reduction with water stress mainly decreased in the number of filled spikelet per panicle ${ }^{[63]}$. Comparison of different irrigation regimes in rice production indicated that flooding irrigation achieved the highest grain yield while intermittent irrigation gave lowest grain yield ${ }^{[41,63]}$. Therefore, it is not surprising that yields were reduced in $\mathrm{R}_{(30 \mathrm{~mm}-90 \%)}$ and $\mathrm{R}_{(30 \mathrm{~mm}-70 \%)}$ that soil drying had a consistent effect on yield since rice is known to be sensitive to non-saturated soil conditions. Some literature reported that the grain yield of rice was reduced by AWD irrigation ${ }^{[7,64]}$ or when exposed to unsaturated soil conditions ${ }^{[8]}$. For soils, the finding of grain yield showed $63.9 \%$ increase in $\mathrm{S}_{(60 \%)}$ compared to $\mathrm{S}_{(40 \%)}$ because the increase in soil clay content resulted in more fine particles that could hold water and nutrient by swelling after watering. therefore, it could retain more water and nutrients needed by the rice plant, consequently raising the number of panicles as well as the filled spikelet per panicle. Similarly, several investigators obtained greater grain yield of rice cultivated in higher clay content soils than those grown in lower clay content soils ${ }^{[42,65]}$. The result of grain yield in Figure 7, with interaction between irrigation method and soil clay content, showed that highly clayed soil holds more water and nutrients providing typical demands for rice. In contrast, the decrease in clay and water content of soil provides an easier passage through its shrinkage, retaining less water including nutrients. That may not meet the demands of rice, in particular during the panicle development and grain filling. The timing of irrigation method applied may interrupt the soil hydrological conditions and cause high water loss, as well as low growth and yield of rice cropped in the heavy soil. The decrease of continuously ponded water on the soil surface can save water, but reduce grain yield of rice ${ }^{[8]}$. In view of the soil type, Carrijo et al. ${ }^{[66]}$ investigated the effect of water management on rice grain yield reporting that yield can be reduced in clayey soil under mild alternative wetting and drying irrigation method. They also discovered that when saving water irrigation technique was applied during the entire growing season; yields were reduced compared to when it was only experienced in either the earlier or later stage.

Harvest index: Higher total dry biomass and grain yield of $\mathrm{R}_{(30 \mathrm{~mm}-100 \%)}$ resulted to higher harvest index indicated that $\mathrm{R}_{(30 \mathrm{~mm}-100 \%)}$ produced more grain mass per unit weight of developed above-ground biomass of rice. Water-saving irrigation technology reduced harvest index due to the reduction in grain yield $^{[67]}$. Harvest indexes found with the present study are similar with previous reports that recorded smaller harvest index under intermittent irrigation (associated with soil desiccation) than in the continuous flooding plot (associated with soil swelling) with no large difference ${ }^{[19]}$. Furthermore, the harvest index was increased with the increase of clay content from $\mathrm{S}_{(40 \%)}$ to $\mathrm{S}_{(60 \%)}$. This increase was attributed to better growth, higher grain and total biomass yield obtained with $\mathrm{S}_{(60 \%)}$ than that obtained with $\mathrm{S}_{(40 \%)}$, indicating the reduction in above-ground biomass was proportional to the decrease in grain yield of rice. Irrigation regime and soil texture combination did not significantly affect the harvest index in this study, While similar result was obtained previously showing no significant differences on harvest index of rice under the interaction between soil texture and irrigation regime ${ }^{[42]}$.

\subsection{Water use efficiency}

Irrigation water productivity: The ANOVA analysis showed significant difference among treatments in irrigation water productivity (Figure 8 ).

The effect of irrigation regime and soil clay content on irrigation water use efficiency was significant at $5 \%$ level (Table 6). However, their interaction was not significant. $R_{(30}$ mm-70\%) showed the lowest mean value of irrigation water productivity (647.8 g/ $\mathrm{m}^{3}$-pipe) while $\mathrm{R}_{(30 \mathrm{~mm}-100 \%)}$ resulted in the highest value of irrigation water use efficiency $\left(1104.5 \mathrm{~g} / \mathrm{m}^{3}\right.$.pipe) but with no significant differences compared to $\mathrm{R}_{(30 \mathrm{~mm}-100 \%)}\left(1092.3 \mathrm{~g} / \mathrm{m}^{3} \cdot\right.$ pipe $)$. Among soils, $\mathrm{S}_{(60 \%)}$ showed the highest IWP (1225.3 g.m $\left.\mathrm{m}^{-3} / \mathrm{pipe}\right)$ 
while $\mathrm{S}_{(40 \%)}$ presented the lowest IWP $\left(702.6 \mathrm{~g} / \mathrm{m}^{3} \cdot\right.$ pipe$)$. The lowest IWP under $\mathrm{R}_{(30 \mathrm{~mm}-70 \%)}$ can be attributed to the sharp reduction in the final plant biomass, which reduced its grain yield by $50.81 \%$ and total amount of evapotranspiration by only $15.11 \%$ compared to $\mathrm{R}_{(30 \mathrm{~mm}-100 \%)}$. Shao el al. ${ }^{[67]}$ revealed similar result that severe soil drying and alternate with higher standing water depth may result in a sharp reduction in grain production of rice which is not favorable for cultivators. Considering the yield as well as the irrigation water use, $\mathrm{R}_{(30 \mathrm{~mm}-100 \%)}$ increased both yield and total evapotranspiration while $\mathrm{R}_{(30 \mathrm{~mm}-90 \%)}$ decreased both yield and total evapotranspiration. Therefore, approximate values of irrigation water use efficiencies were obtained. The present results indicate that IWP might not be a precise indicator for the best water management practice, particularly in cracked soil. However, $\mathrm{R}_{(30 \mathrm{~mm}-90 \%)}$ seemed to be more applicable than $\mathrm{R}_{(30 \mathrm{~mm}-100 \%)}$ in clayed soil due to water scarcity. $\quad$ Lu el al. ${ }^{[19]}$ found no significant difference in IWP for continuous flooding and intermittent irrigation regimes, while, maintaining the soil continuously around saturation reduced yields per water inputs but increased water productivity compared with flooded conditions in transplanted rice ${ }^{[64]}$. The highest value of IWP in $\mathrm{S}_{(60 \%)}$ is only attributed to the increase in grain yield by $39.99 \%$ compared to $\mathrm{S}_{(40 \%)}$ since the total evapotranspiration between $\mathrm{S}_{(60 \%)}$, and $\mathrm{S}_{(40 \%)}$ had no significant difference (Table 4).

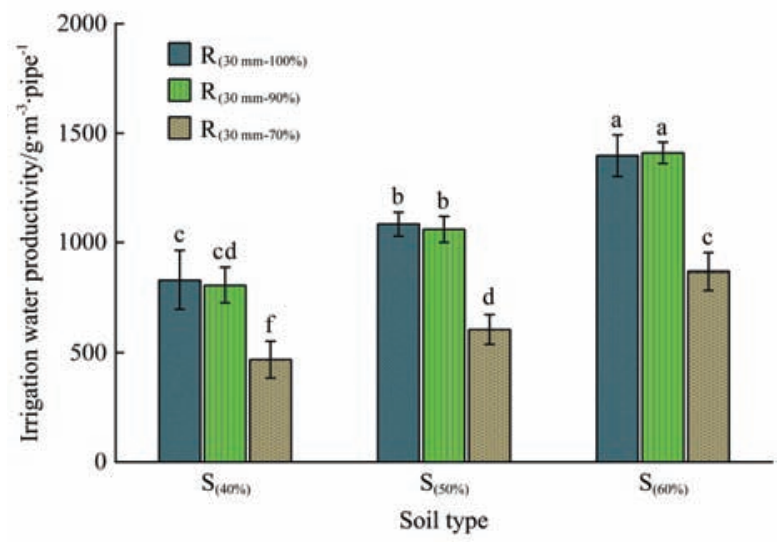

Figure 8 The impact of water regime and soil clay content on irrigation water use efficiency

Total water productivity: The analysis of variance shows significant difference among treatments in total water productivity (Figure 9).

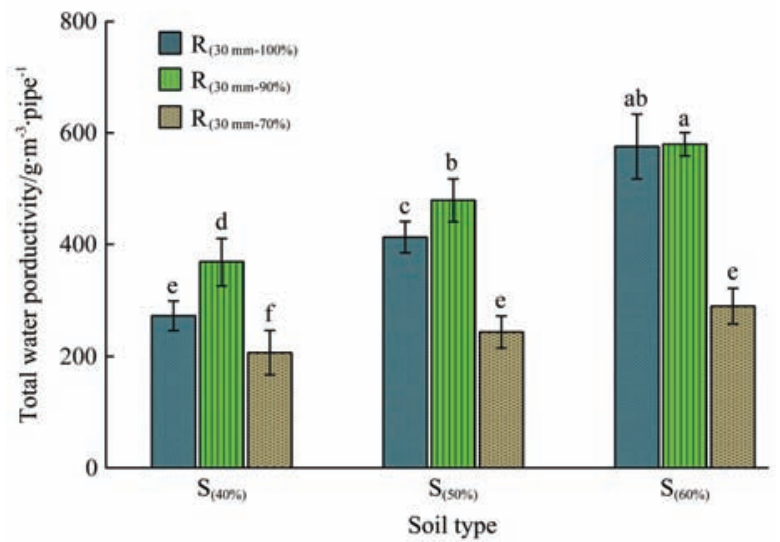

Figure 9 Total water use efficiency as affected by water regime and soil clay content

Total water productivity was significantly affected by the method of irrigation, soil clay content and their combination at $5 \%$ level (Table 6). The TWP under $\mathrm{R}_{(30 \mathrm{~mm}-90 \%)}\left(475.8 \mathrm{~g} / \mathrm{m}^{3} \cdot\right.$ pipe) was markedly higher than that under $R_{(30 \mathrm{~mm}-100 \%)}\left(420.5 \mathrm{~g} / \mathrm{m}^{3} \cdot\right.$ pipe $)$ and $\mathrm{R}_{(30 \mathrm{~mm}-70 \%)}\left(247 \mathrm{~g} / \mathrm{m}^{3} \cdot\right.$ pipe $)$. $\mathrm{S}_{(60 \%)}$ showed higher TWP $\left(481.9 \mathrm{~g} / \mathrm{m}^{3} \cdot\right.$ pipe $)$ than $\mathrm{S}_{(40 \%)}\left(282.8 \mathrm{~g} / \mathrm{m}^{3} \cdot\right.$ pipe $)$. Under the interaction, the highest and the lowest value of total water productivity were found in $\mathrm{R}_{(30 \mathrm{~mm}-90 \%)} \mathrm{S}_{(60 \%)}$ and $\mathrm{R}_{(30 \mathrm{~mm}-70 \%)} \mathrm{S}_{(40 \%)}$ treatments as $579.6 \mathrm{~g} / \mathrm{m}^{3}$.pipe and $206.8 \mathrm{~g} / \mathrm{m}^{3}$.pipe, respectively (Figure 7).

Table 6 Yield indicators and water use efficiency of rice as affected by water regime and soil clay content

\begin{tabular}{|c|c|c|c|c|c|}
\hline \multirow{2}{*}{$\begin{array}{c}\text { Factor } \\
\text { Regime (R) }\end{array}$} & \multicolumn{3}{|c|}{ Yield component } & \multicolumn{2}{|c|}{ Efficiency indicator } \\
\hline & $\begin{array}{c}\text { Total } \\
\text { Biomass } \\
/ \mathrm{g} \cdot \text { pipe }^{-1}\end{array}$ & $\begin{array}{l}\text { Grains } \\
\text { Mass } \\
/ \mathrm{g} \cdot \text { pipe }^{-1}\end{array}$ & $\begin{array}{l}\text { Harvest } \\
\text { index } / \%\end{array}$ & $\begin{array}{l}\text { Irrigation water } \\
\text { productivity } \\
/ \mathrm{g} \cdot \mathrm{m}^{-3} \cdot \mathrm{pipe}^{-1}\end{array}$ & $\begin{array}{l}\text { Total water } \\
\text { productivity } \\
/ \mathrm{g} \cdot \mathrm{m}^{-3} \cdot \text { pipe }^{-1}\end{array}$ \\
\hline $\mathrm{R}_{(30 \mathrm{~mm}-100 \%)}$ & $34.04^{\mathrm{a}}$ & $16.63^{\mathrm{a}}$ & $48.85^{\mathrm{a}}$ & $1104.5^{\mathrm{a}}$ & $420.5^{\mathrm{b}}$ \\
\hline $\mathrm{R}_{(30 \mathrm{~mm}-90 \%)}$ & $29.18^{\mathrm{b}}$ & $14.05^{\mathrm{b}}$ & $47.99^{b}$ & $1092.3^{\mathrm{a}}$ & $475.8^{\mathrm{a}}$ \\
\hline $\mathrm{R}_{(30 \mathrm{~mm}-70 \%)}$ & $17.92^{\mathrm{c}}$ & $8.18^{\mathrm{c}}$ & $45.42^{\mathrm{c}}$ & $647.8^{\mathrm{c}}$ & $247^{\mathrm{c}}$ \\
\hline$p$-value & 0 & 0 & 0 & 0 & 0 \\
\hline \multicolumn{6}{|c|}{ Soil type (S) } \\
\hline $\mathrm{S}_{(40 \%)}$ & $21.27^{\mathrm{c}}$ & $9.89^{\mathrm{c}}$ & $46.13^{c}$ & $702.6^{\mathrm{c}}$ & $282.8^{\mathrm{c}}$ \\
\hline $\mathrm{S}_{(50 \%)}$ & $26.66^{\mathrm{b}}$ & $12.77^{\mathrm{b}}$ & $47.53^{b}$ & $916.8^{\mathrm{b}}$ & $378.6^{\mathrm{b}}$ \\
\hline $\mathrm{S}_{(60 \%)}$ & $33.22^{\mathrm{a}}$ & $16.21^{\mathrm{a}}$ & $48.43^{\mathrm{a}}$ & $1225.3^{\mathrm{a}}$ & $481.9^{\mathrm{a}}$ \\
\hline$p$-value & 0 & 0 & 0 & 0 & 0 \\
\hline \multicolumn{6}{|c|}{ Interaction $(\mathrm{R} \times \mathrm{S})$} \\
\hline$p$-value & 0 & 0 & 0.26 & 0.16 & 0 \\
\hline
\end{tabular}

Note: In the column, averages followed by the common letter(s) are not significantly different at the level of $p \leq 5 \%$ according to Duncan's Multiple Range Test. $R \times S$ means the interaction between irrigation regime $(R)$ and soil type (S).

Although the production of grain in $\mathrm{R}_{(30 \mathrm{~mm}-90 \%)}$ decreased $15.5 \%$ from that in $\mathrm{R}_{(30 \mathrm{~mm}-100 \%)}$, an $11.6 \%$ increase in total water use efficiency was achieved in $\mathrm{R}_{(30 \mathrm{~mm}-90 \%)}$ due to the $27.7 \%$ less amount of total applied water. On the other side, the higher grain yield by $71.76 \%$ and lower water use by $10.8 \%$ in $\mathrm{R}_{(30 \mathrm{~mm}-90 \%)}$ increased total water productivity by $92.53 \%$ compared to $\mathrm{R}_{(30 \mathrm{~mm}-70 \%)}$. In $\mathrm{R}_{(30 \mathrm{~mm}-70 \%)}$, both the lowest production of grain and highest loss of total water resulted in the lowest total water use efficiency. The reduction of water productivity of rice in cracking clay soils was attributed to the preferential flow in which water consumption was increased ${ }^{[68]}$. Further, the effects of drought duration, drought severity, and drought timing on the rice production were investigated by Bouman and Tuong ${ }^{[8]}$. They found that the alternating drying could result in shrinkage and desiccation, thereby enhancing the risk of soil water leakage, enlarged water needs, and decreased water productivity in the clay textured soil ${ }^{[8]}$. The water loss of AWD in the experiment conducted clay soil was not reduced as expected due to a great amount of soil cracking. Therefore, water productivity was not significantly improved by AWD compared with continues flooding irrigation $^{[69]}$. The increase in clay content from $40 \%$ to $60 \%$ could raise total water use efficiency by $70.4 \%$. This was due to the reason that the increase in clay content from $40 \%$ to $60 \%$ increased the production of grain yield by $63.9 \%$ and reduced the total water consumption by $4.9 \%$. Dou el al. ${ }^{[42]}$ reported the same result that water regime and soil texture significantly affected yield and water use efficiency of rice. As irrigation intervals decreased water usage, the cracks enlarged resulting in a sharp reduction in growth and grain yield. Therefore; $\mathrm{R}_{(30 \mathrm{~mm}-70 \%)} \mathrm{S}_{(40 \%)}$ showed the lowest value of TWP while soil cracking under $\mathrm{R}_{(30 \mathrm{~mm}-90 \%)} \mathrm{S}_{(60 \%)}$ had a less impact on water losses and grain yield which improved TWP. 
As a result, the excessive amount of soil cracking must be avoided in rice cropping since alternate wetting and drying conduction for a long time can help in decreasing water use efficiency due to a great amount of soil cracking ${ }^{[19]}$, while the bypass or preferential flow and nitrogen transformation under saving-water irrigation can also help in reducing the water saving effectiveness ${ }^{[60]}$.

\section{Conclusions}

Irrigation regime is the main factor in determining water consumption and the efficiency of water use in rice cultivated in the clay-textured soil. The increase in soil clay content from $40 \%$ to $60 \%$ increased growth, yield, and water productivity of rice. In the finer textured soils, maintaining soil water content as close to saturation as possible and reflooding showed a significant increase in plant growth and grain yield, but decreased water productivity due to the increase in water consumption. Allowing rich clay soil to dry $10 \%$ below the saturation and then re-flooding enhances the water productivity since the small amount reduction in water use did not significantly affect plant growth and grain yield. Decreasing soil moisture content $30 \%$ below the saturation and then re-flooding results in a sharp reduction in growth, yield, and water use efficiency of rice due to a great amount of soil cracking, which is not desirable for farmers. The formation of soil cracks depends on the irrigation regime as well as on the soil clay content. Therefore, it is highly recommended that soil cracking must be avoided for rice yielding and irrigation-water conserving.

\section{Acknowledgment}

This research is supported by the National Natural Science Foundation of China (51079042 and 51309080) and Water Conservancy Science and Technology Project of Jiangsu Province.

\section{[References]}

[1] Zhang X, Wang D, Fang F, Zhen Y, Liao X. Food safety and rice production in China. Res Agric Modernization, 2005; 26: 85-88.

[2] Chauhan B S, Jabran K, Mahajan G. Rice production worldwide. Cham, Switzerland: Sprinker International Publishing, 2017.

[3] Frolking S, Qiu J, Boles S, Xiao X, Liu J, Zhuang Y, Li C, Qin X. Combining remote sensing and ground census data to develop new maps of the distribution of rice agriculture in China. Global Biogeochemical Cycles, 2002; 16(4): 31-38.

[4] Li Y. Water saving irrigation in China. Irrigation and Drainage, 2006; 55(3): 327-336.

[5] Cai H, Chen Q. Rice production in China in the early 21 st century chinese rice research newsletter. Rice Science, 2000; 8(2): 14-16.

[6] Maclean J L, Dawe D C, Hardy B, Hettel G P. Rice almanac. International Rice Research Institute, West Africa Rice Development Association. International Center for Tropical Agriculture, Food and Agriculture Organization. CAB International, Wallingford, UK, 2002.

[7] Belder P, Bouman B A, Cabangon R, Guoan L, Quilang E J, Yuanhua L, Spiertz J H, Tuong T P. Effect of water-saving irrigation on rice yield and water use in typical lowland conditions in Asia. Agricultural Water Management, 2004; 65(3): 193-210.

[8] Bouman B, Tuong T P. Field water management to save water and increase its productivity in irrigated lowland rice. Agricultural Water Management, 2001; 49(1): 11-30.

[9] Cabangon R J, Tuong T P, Castillo E G, Bao L X, Lu G, Wang G, Cui Y, Bouman B A, Li Y, Chen C, Wang J. Effect of irrigation method and $\mathrm{N}$-fertilizer management on rice yield, water productivity and nutrient-use efficiencies in typical lowland rice conditions in China. Paddy and Water Environment, 2004; 2(4): 195-206

[10] Linquist B A, Anders M M, Adviento - Borbe M A, Chaney R L, Nalley L L, Da Rosa E F, Kessel C. Reducing greenhouse gas emissions, water use, and grain arsenic levels in rice systems. Global change biology, 2015; 21(1): 407-417.
[11] Lampayan R M, Rejesus R M, Singleton G R, Bouman B A. Adoption and economics of alternate wetting and drying water management for irrigated lowland rice. Field Crops Research, 2015; 170: 95-108.

[12] Belder P, Spiertz J H, Bouman B A, Lu G, Tuong T P. Nitrogen economy and water productivity of lowland rice under water-saving irrigation. Field Crops Research, 2005; 93(2): 169-185.

[13] Dinka T M, Lascano R J. Challenges and limitations in studying the shrink-swell and crack dynamics of vertisol soils. Open Journal of Soil Science, 2012; 2(2): 82.

[14] Lal R, Shukla M K. Principles of soil physics. CRC Press, 2004.

[15] Sander T, Gerke H. Preferential flow patterns in paddy fields using a dye tracer. Vadose Zone Journal, 2007; 6(1): 105-115.

[16] Battany M, Grismer M. Rainfall runoff and erosion in Napa Valley vineyards: effects of slope, cover and surface roughness. Hydrological processes, 2000; 14(7): 1289-1304.

[17] Greve A, Andersen M, Acworth R. Investigations of soil cracking and preferential flow in a weighing lysimeter filled with cracking clay soil. Journal of Hydrology, 2010; 393(1): 105-113.

[18] Arnold J, Potter K, King K, Allen P. Estimation of soil cracking and the effect on surface runoff in a Texas Blackland Prairie watershed. Hydrological Processes., 2005; 19(3): 589-603.

[19] Lu J, Ookawa T, and HirasawaT. The effects of irrigation regimes on the water use, dry matter production and physiological responses of paddy rice. Plant and Soil, 2000; 223(1): 209-218.

[20] Bandyopadhyay K K, Mohanty M, Painuli D K, Misra A K, Hati K M, Mandal K G, et al., Influence of tillage practices and nutrient management on crack parameters in a Vertisol of central India. Soil and Tillage Research., 2003; 71(2): 142-133.

[21] Weisbrod N, Dragila I M, Nachshon U, Pillersdorf M. Falling through the cracks: The role of fractures in earth-atmosphere gas exchange. Geophysical Research Letters, 2009; 36(2): 270-271.

[22] Ritchie J, Adams J. Field measurement of evaporation from soil shrinkage cracks. Soil Science Society of America Journal, 1974; 38(1): 131-134.

[23] Cabangon R, Castillo E, Tuong T. Chlorophyll meter-based nitrogen management of rice grown under alternate wetting and drying irrigation. Field Crops Research, 2011; 121(1): 136-146.

[24] Day P R. Particle fractionation and particle-size analysis. Methods of soil analysis. Part 1. Physical and mineralogical properties, including statistics of measurement and sampling. Methods of Soil Analysis, 1965; 545-567.

[25] Klute A. Methods of Soil Analysis. Part 1. Physical and Mineralogical Methods; SSSA Book Series 5. Soil Science Society of America: Madison WI, 1986.

[26] Schofield R, Taylor W A. The measurement of soil pH. Soil Science Society of America Journal, 1955; 19(2): 164-167.

[27] Corwin D, Rhoades J. An improved technique for determining soil electrical conductivity depth relations from aboveground electromagnetic measurements. Soil Science Society of America Journal, 1982; 46(3): 517-520.

[28] Walkley A, Black A I. An examination of the Degtjareff method for determining soil organic matter, and a proposed modification of the chromic acid titration method. Soil Science, 1934; 37(1): 29-38.

[29] Jackson M L. Soil Chemical Analysis. Prentice Hall, Englewood Cliffs, NJ. 1958.

[30] Searle P L. The Berthelot or indophenol reaction and its use in the analytical chemistry of nitrogen: A review. Analyst, 1984; 109(5): 549-568.

[31] Henriksen A, Selmer-Olsen A. Automatic methods for determining nitrate and nitrite in water and soil extract. Analyst, 1970; 95(1130): $514-518$.

[32] Sims J, Jackson G. Rapid analysis of soil nitrate with chromotropic acid Soil Science Society of America Journal, 1971; 35(4): 603-606.

[33] Murphy J, Riley P J. A modified single solution method for the determination of phosphate in natural waters. Analytica Chimica Acta, 1962; 27: 31-36.

[34] Sharma P K, Verma S T, Bhagat M R. Soil structural improvements with the addition of Lantana camara biomass in rice-wheat cropping. Soil Use and Management., 1995; 11(4): 199-203.

[35] Elias E, Salih A, Alaily F. Cracking patterns in the vertisols of the Sudan Gezira at the end of dry season. International Agrophysics, 2001; 15(3): $151-156$. 
[36] Flowers M, Lal R. Axle load and tillage effects on the shrinkage characteristics of a Mollic Ochraqualf in northwest Ohio. Soil and Tillage Research, 1999; 50(3): 251-258.

[37] Novak V, Šimåunek J, Genuchten M T. Infiltration of water into soil with cracks. Journal of Irrigation and Drainage Engineering, 2000; 126(1): 41-47.

[38] Sharma P K, Bhushan L, Ladha J K, Naresh R K, Gupta R K, Balasubramanian $\mathrm{B} \mathrm{V}$, et al. Crop-water relations in rice-wheat cropping under different tillage systems and water-management practices in a marginally sodic, medium-textured soil. Water-wise rice production. International Rice Research Institute, Los Baños, Philippines, 2002; 8: 223-235.

[39] Kirby J, Ringrose-Voase A. Drying of some Philippine and Indonesian puddled rice soils following surface drainage: numerical analysis using a swelling soil flow model, Soil and Tillage Research, 2000; 57(1-2): $13-30$

[40] Cabangon R J, Tuong T P. Management of cracked soils for water saving during land preparation for rice cultivation. Soil and Tillage Research, 2000; 56(1): 105-116.

[41] Borrell A, Garside A, Fukai S. Improving efficiency of water use for irrigated rice in a semi-arid tropical environment. Field Crops Research, 1997; 52(3): 231-248.

[42] Dou F, Soriano J, Tabien R E, Chen K. Soil texture and cultivar effects on rice (Oryza sativa L.) grain yield, yield components and water productivity in three water regimes. PloSOne, 2016; 11(3).

[43] Styger E. System of rice intensification (SRI)-Community-based evaluation in Goundam and Dire Circles, Timbuktu, Mali, 2008/2009.

[44] Mostafazadeh-Fard B, Jafari F, Mousavi S F, Yazdani M R. Effects of irrigation water management on yield and water use efficiency of rice in cracked paddy soils. Australian journal of crop science, 2010; 4(3): 136.

[45] Sahrawat K L. Soil fertility in flooded and non-flooded irrigated rice systems. Archives of Agronomy and Soil Science, 2012; 58(4): 423-436.

[46] Bunnag S, Pongthai P. Selection of rice (Oryza sativa L.) cultivars tolerant to drought stress at the vegetative stage under field conditions. American Journal of Plant Sciences, 2013; 4(9): 1701.

[47] Zhang X, Wang J, Huang J, Lan H, Wang C, Yin C, Wu Y, Tang H, Qian Q, Li J, Zhang H. Rare allele of OsPPKL1 associated with grain length causes extra-large grain and a significant yield increase in rice. Proceedings of the National Academy of Sciences, 2012; 109(52): 21534-215349.

[48] Kobayasi K, Horie Y, Imaki T. Relationship between apical dome diameter at panicle initiation and the size of panicle components in rice grown under different nitrogen conditions during the vegetative stage. Plant Production Science, 2002; 5(1): 3-7.

[49] Cheng F M, Zhang Q F, Zhu H J, Zhao N C, Wang F, Chen K M, Zhang G P. The difference in amylose content within a panicle as affected by the panicle morphology of rice cultivars. Journal of Cereal Science, 2007; 46(1): 49-57.

[50] Xing Y, Zhang Q. Genetic and molecular bases of rice yield. Annual Review of Plant Biology, 2010; 61: 421-442.

[51] Manivannan S, Balamurugan M, Parthasarathi K, Gunasekaran G, Ranganathan L S. Effect of vermicompost on soil fertility and crop productivity-Beans (Phaseolus vulgaris). Journal of Environmental Biology, 2009; 30(2): 275-281.

[52] Yoshida S. Fundamentals of rice crop science. International Rice Research Institute, Los Baños, 1981.
[53] Kibria M G. Dynamics of cadmium and lead in some soils of Chittagong and their influx in some edible crops. $\mathrm{PhD}$ thesis, University of Chittagong, Bangladesh, 2008; 292p.

[54] Cairns J E, Audebert A, Townend J, Price A H, Mullins C E. Effect of soil mechanical impedance on root growth of two rice varieties under field drought stress. Plant and Soil, 2004; 267(1-2): 309-318.

[55] Gardner C M, Laryea B K, Unger W P. Soil physical constraints to plant growth and crop production. Land and Water Development Division, Food and Agriculture Organization, 1999.

[56] Kondo M, Pablico P P, Aragones D V, Agbisit R, Abe J, Morita S, Courtois B. Genotypic and environmental variations in root morphology in rice genotypes under upland field conditions. InRoots: The Dynamic Interface between Plants and the Earth, Springer, Netherland, 2003; pp.189-200.

[57] Valizadeh M R, Rahimi-Ajdadi F, Dabbaghi A. Cutting energy of rice stem as influenced by internode position and dimensional characteristics of different varieties. Australian Journal of Crop Science, 2011; 5(6): 681-687.

[58] Lee Y, Kende H. Expression of $\alpha$-expansin and expansin-like genes in deepwater rice. Plant Physiology, 2002; 130(3): 1396-1405.

[59] Shao H B, Chu L Y, Shao M A, Jaleel C A, Mi H M. Higher plant antioxidants and redox signaling under environmental stresses. Comp Rend Biol, 2008; 331: 433-441.

[60] Usman M R Z F, Raheem Z, Iqbal A, Sarfaraz Z N, Haq Z. Morphological, physiological and biochemical attributes as indicators for drought tolerance in rice (Oryza sativa L.). Pakistan Journal of Biological Sciences, 2012; 5(1): 23-28.

[61] Castillo E, Buresh B, Ingram K. Lowland rice yield as affected by timing of water deficit and nitrogen fertilization. Agronomy Journal, 1992; 84(2): 152-159.

[62] Tsubo M, Fukai S, Basnayake J, Tuong T P, Bouman B, Harnpichitvitaya D. Effects of soil clay content on water balance and productivity in rainfed lowland rice ecosystem in Northeast Thailand. Plant Production Science, 2007; 10(2): 232-241.

[63] Beşer N. The effects of planting and irrigation methods on yield and yield components and quality characters in rice (Oryza sativa L.). Doktora tezi, TÜ Fen Bilimleri Enstitüsü, Edirne, 1997.

[64] Tabbal D F, Bouman B A, Bhuiyan S I, Sibayan E B, Sattar M A. On-farm strategies for reducing water input in irrigated rice; case studies in the Philippines. Agricultural Water Management, 2002; 56(2): 93-112.

[65] Rao P R, Subrhamanyam D, Sailaja B, Singh R P, Ravichandran V, Rao G S, Swain P, Sharma S G, Saha S, Nadaradjan S, Reddy P J. Influence of boron on spikelet fertility under varied soil conditions in rice genotypes. Journal of Plant Nutrition, 2013; 36(3): 390-400.

[66] Carrijo D R, Lundy E M, Linquist A B. Rice yields and water use under alternate wetting and drying irrigation: A meta-analysis. Field Crops Research, 2017; 203: 173-180.

[67] Shao G C, Deng S, Liu N, Yu SE, Wang M H, She D L. Effects of controlled irrigation and drainage on growth, grain yield and water use in paddy rice. European Journal of Agronomy, 2014; 53: 1-9.

[68] Islam M J, Parul S S, Pathan A B, Islam M S, Quasem M A. Influence of cracking on rice seasons and irrigation in Bangladesh. Journal of Biological Sciences, 2004; 4(1): 11-14.

[69] Tan X, Shao D, Liu H, Yang F, Xiao C, Yang H. Effects of alternate wetting and drying irrigation on percolation and nitrogen leaching in paddy fields. Paddy and Water Environment, 2013; 11(1-4): 381-395. 